\title{
48. SEDIMENTATION ON FENI AND GARDAR SEDIMENT DRIFTS 1
}

\author{
Robert B. Kidd, Institute of Oceanographic Sciences, Wormley, United Kingdom \\ and \\ Philip R. Hill, Geological Survey of Canada, Atlantic Geoscience Centre, Dartmouth, Nova Scotia ${ }^{2}$
}

\begin{abstract}
Feni and Gardar ridges are two major North Atlantic sediment drifts-positive sedimentary accumulations over $1600 \mathrm{~m}$ thick presumed to result from sediment distribution by bottom water circulation since Eocene-Oligocene time. At Deep Sea Drilling Project Sites 610 and 611 we penetrated the Miocene to Holocene sequences of these drifts, and we looked for depositional changes across sediment wave fields on their surfaces with a series of offset holes.

The sediment waves, over $20 \mathrm{~m}$ in height and over $2 \mathrm{~km}$ in wavelength, are morphologically more complex than hitherto recognized. Around the drill sites, waves characterize the upper 100 to $200 \mathrm{~m}$ of seismic sections, but we found no evidence of wave migration in these records.

Lithologies in the sediment waves are fundamentally pelagic. Few current-produced sedimentary structures or hiatuses were found. Glacial cycles allow detailed wave-to-trough correlations, which show that since $2.4 \mathrm{Ma}$, little or no wave migration could have occurred. Sedimentation rate differences between wave and trough locations suggest that wave migration did occur in the Pliocene at the Gardar Ridge site.

A review of possible sedimentary processes and parameters indicates that internal waves in a stratified water column might be important for the initiation and migration of sediment waves.

Changes in sedimentary regime on the drifts seem to be linked to interaction between bottom water masses from northern (Norwegian Sea Overflow Water-NSOW) and southern (Antarctic Bottom Water-AABW; and North Atlantic Deep Water-NADW) sources and not to changes in intensity of NSOW alone. Regional seismic reflectors drilled at the Feni Ridge site are linked to oceanographic changes: "R2" of early Miocene age appears to signify a silica productivity event; "R1" of late Miocene age could be linked to the isolation of the Mediterranean, which may have affected the NADW slope current.

Our interpretation of the sedimentary history of the drifts is that during the preglacial period NSOW was probably the dominant bottom water mass over the drifts and the sediment waves were actively migrating. We suggest that the influence of NSOW lessened with the onset of the glacial-interglacial periods. Since that time, bottom currents have simply "maintained" the morphology of the now largely relict wave fields.
\end{abstract}

\section{INTRODUCTION}

The long-term effects of oceanic bottom water circulation on deep marine sedimentation are most clearly seen on seismic reflection records taken from middle to high latitudes. They appear as anomalous sediment accumulations known as sediment drifts. These may be over $1 \mathrm{~km}$ in thickness, with a relief of hundreds of meters, and may run as longitudinal features of the seafloor for hundreds of kilometers (Table 1).

Sediment drifts have been described extensively from the North Atlantic (Hollister et al., 1978); most of the larger, named features appear in Figure 1 and Table 1. Lonsdale (1982) defines three varieties: (1) projections from continental rises (e.g., the Bahama Outer Ridge); (2) isolated ridges detached from a continental margin (e.g., the Greater Antilles Outer Ridge); and (3) midocean sediment ridges banked up against preexisting topography (e.g., the Bermuda Rise). Some sediment drifts may be a combination of these types. Smaller-scale sediment ridges are widespread on many continental margins where they are built around topographic highs that

\footnotetext{
${ }^{1}$ Ruddiman, W. F., Kidd, R. B., Thomas, E., et al., Init. Repts. DSDP, 94: Washington (U.S. Govt. Printing Office).

2 Addresses: (Kidd, present address) Dept. of Geology, University College of Swansea, Singleton Park, Swansea, SA2 8PP, Wales, United Kingdom; (Hill) Geological Survey of Canada, Atlantic Geoscience Centre, P.O. Box 1006, Dartmouth, Nova Scotia, Canada B2Y 4A2.
}

interrupt along-slope bottom water flow (Heezen and Hollister, 1971; Hogg, 1980). Sediment drifting is so widespread on the Iberian continental margin, for example, that it is believed to have been a major factor in sediment distribution there throughout the Cenozoic (Kidd and Roberts, 1982; Roberts and Kidd, 1985; Gardner and Kidd, in press). Similarly, in parts of the Mid-Atlantic Ridge flank province (such as the Reykjanes Ridge) that come under the influence of vigorous North Atlantic bottom water circulation, the earliest sedimentary deposits over young ocean crust suffer extensive drifting. Here the interaction between rough basement topography and current regime plays a major role in sediment distribution (Ruddiman, 1972).

Two sites in the DSDP Leg 94 paleoclimate traverse (Fig. 2) were to be drilled in the Feni Ridge (Site 610) and the Gardar Ridge (Site 611), both known sediment drifts. An expanded upper Neogene and Quaternary section was predicted at the sites because of expected aboveaverage oceanic sedimentation rates. A further objective at these two sites was to drill beyond the glacial-interglacial section in order to document the history of sedimentation on the drifts. We were keen to compare and contrast changes that might appear between deposits accumulating under glacial, interglacial, and preglacial conditions, because no systematic sedimentologic documentation had been made previously of the typical lithologies that build sediment drifts through time. 
Table 1. North Atlantic sediment drift features.

\begin{tabular}{|c|c|c|c|c|}
\hline $\begin{array}{c}\text { Drift } \\
\text { name } \\
\text { (abbreviation) }\end{array}$ & $\begin{array}{l}\text { Approximate } \\
\text { length } \\
(\mathrm{km})\end{array}$ & $\begin{array}{l}\text { Approximate } \\
\text { width } \\
(\mathrm{km})\end{array}$ & $\begin{array}{l}\text { Thickness } \\
\text { to basal } \\
\text { reflector } \\
\text { (m) }\end{array}$ & References \\
\hline $\begin{array}{l}\text { Bahama Outer Ridge } \\
\text { (BOR) }\end{array}$ & 600 & 400 & 600 & $\begin{array}{l}\text { Hollister, Ewing, et al., 1972; } \\
\text { Flood and Hollister, } \\
\text { 1974; Flood, 1983; Kidd } \\
\text { and Roberts, } 1982\end{array}$ \\
\hline Bermuda Rise (BR) & 700 & 90 & 1000 & $\begin{array}{l}\text { Embley et al., 1980; Laine } \\
\text { and Hollister, 1981; } \\
\text { Flood, } 1983\end{array}$ \\
\hline $\begin{array}{l}\text { Blake Outer Ridge } \\
\text { (BBOR) }\end{array}$ & 600 & 400 & 600 & $\begin{array}{l}\text { Hollister, Ewing, et al., 1972; } \\
\text { Flood and Holister, } \\
\text { 1974; Flood 1983; } \\
\text { Tucholke, 1979; Kidd } \\
\text { and Roberts, 1982 }\end{array}$ \\
\hline Bjorn Drift (BD) & 830 & 100 & 600 & McCave et al., 1980 \\
\hline $\begin{array}{l}\text { Caicos Outer Ridge } \\
\text { (COR) }\end{array}$ & 333 & 100 & 1425 & $\begin{array}{l}\text { Schneider and Heezen, 1966; } \\
\text { Embley et al., 1980; } \\
\text { Laine and Hollister, } 1981\end{array}$ \\
\hline Corner Rise (CR) & 700 & 148 & 750 & $\begin{array}{l}\text { McGregor et al., 1973; Laine } \\
\text { and Hollister, 1981 }\end{array}$ \\
\hline Eirik Drift (ED) & 355 & 230 & - & $\begin{array}{l}\text { Johnson and Schneider, } \\
\text { 1969; Davies and Laugh- } \\
\text { ton, 1972; Egloff and } \\
\text { Johnson, } 1975\end{array}$ \\
\hline Feni Drift (FD) & 600 & 100 & $1500-1700$ & $\begin{array}{l}\text { Flood, 1978; Flood et al., } \\
\text { 1979; Kidd and Roberts, } \\
\text { 1982; Stow, 1982; Kidd } \\
\text { and Hill, in press }\end{array}$ \\
\hline Gardar Drift (GD) & 1000 & 130 & $1300-1600$ & $\begin{array}{l}\text { Johnson and Schneider, } \\
\text { 1969; Ruddiman, 1972; } \\
\text { McCave et al., 1980; } \\
\text { Kidd and Hill, in press }\end{array}$ \\
\hline Gloria Drift (GRD) & 375 & 330 & $900-1400$ & $\begin{array}{l}\text { Davies and Laughton, 1972; } \\
\text { Egloff and Johnson, } \\
1975\end{array}$ \\
\hline $\begin{array}{l}\text { Greater Antilles } \\
\text { Outer Ridge } \\
\text { (GAOR) }\end{array}$ & 1800 & 220 & 700 & $\begin{array}{l}\text { Tucholke and Ewing, 1974; } \\
\text { Tucholke, 1975; Flood, } \\
\text { 1978, 1983 }\end{array}$ \\
\hline $\begin{array}{l}\text { Gulf Stream Drift } \\
\text { (GSD) }\end{array}$ & 120 & 70 & 750 & Laine and Hollister, 1981 \\
\hline $\begin{array}{l}\text { Hatteras Outer } \\
\text { Ridge (HAT) }\end{array}$ & $500-550$ & 50 & 1300 & $\begin{array}{l}\text { Richardson, 1977; Tucholke } \\
\text { and Laine, 1982; Van } \\
\text { Hinte et al., 1985 }\end{array}$ \\
\hline Hatton Drift (JD) & 65 & 50 & 700 & $\begin{array}{l}\text { Ruddiman, 1972; McCave et } \\
\text { al., } 1980\end{array}$ \\
\hline $\begin{array}{l}\text { Hudson Drift } \\
\text { (HUD) }\end{array}$ & 30 & 5 & 40 & Lowrie and Heezen, 1967 \\
\hline Isengard Drift (ID) & 480 & 72 & - & $\begin{array}{l}\text { Roberts et al., 1979; Flood, } \\
1978\end{array}$ \\
\hline $\begin{array}{l}\text { Newfoundland Outer } \\
\text { Ridge (NOR) }\end{array}$ & 500 & 200 & 400 & $\begin{array}{l}\text { Grabovskiy, 1966; Grant, } \\
\text { 1972; Pastouret et al., } \\
\text { 1975 }\end{array}$ \\
\hline Snorri Drift (SD) & 250 & 100 & $300-500$ & $\begin{array}{l}\text { Luyendyk, Cann, et al., } \\
\text { 1979; Shor and Poore, } \\
\text { 1979; McCave et al., } \\
\text { 1980 }\end{array}$ \\
\hline
\end{tabular}

Note: $-=$ no data available. 


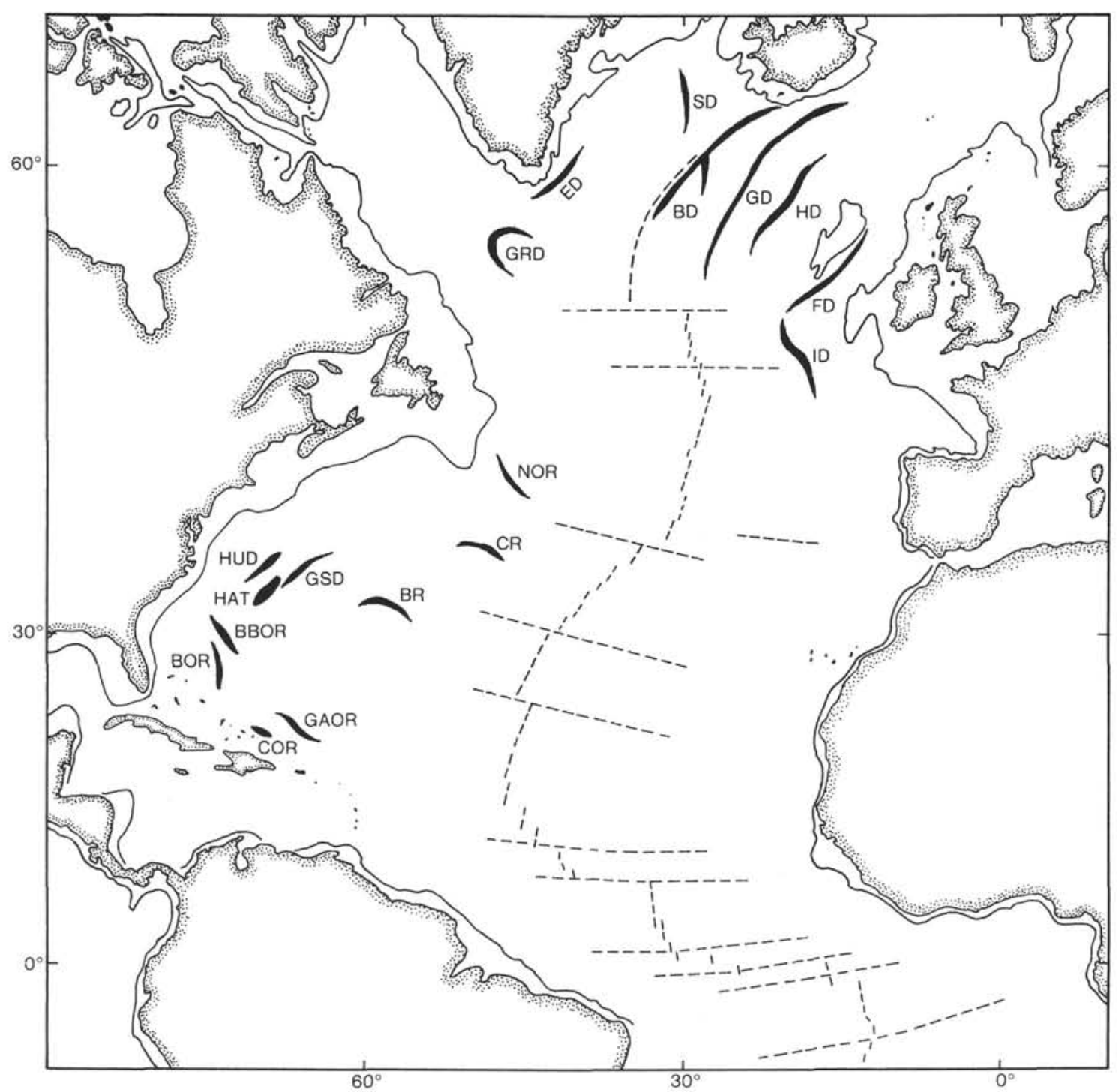

Figure 1. Location of the major North Atlantic sediment drifts (see Table 1 for letter codes and details on individual drifts).

The detailed bathymetry over sediment drifts is frequently characterized by sediment waves: large-scale sedimentary bed forms that are generally tens of meters in amplitude and up to a few kilometers in wavelength (Table 2). Sediment wave fields were known to occur in the vicinity of both proposed Leg 94 sites (Roberts and Kidd, 1979). Understanding the development of the sediment waves and their relationship to the modern circulation was seen as a precursor to understanding the history of sedimentation of the drift accumulations as a whole. Excellent weather and operational conditions during the leg meant that contingency time could be used to develop another objective for the sites. This involved offset hydraulic piston coring-spacing holes with respect to the sediment wave crests and troughs-to learn more of the structure of the wave fields and their recent history of accumulation (Fig. 3). This objective could be carried out at the same time as drilling the overlapping holes necessary to obtain a complete high-resolution stratigraphy for the sites.
The general results of our drilling at Site 610, located near the crest of Feni Ridge, and at Site 611, in a lower flank setting on Gardar Ridge, were surprising. The ages of the upper seismic reflectors in the sediment drifts were younger than predicted by some authors. The lithologies were fundamentally pelagic and lacked sedimentary structures indicative of bottom water activity. The sediment waves showed no clear evidence of migration during the Quaternary, but sedimentation-rate changes indicated that migration had occurred in the Pliocene. So many of our findings were contrary to previous ideas about the structure and development of sediment drifts and their sediment waves that we found it difficult to filter the positive results and place them in the context of a synthesis on North Atlantic drift sedimentation.

In this chapter, we present the information that we collected on these two oceanic drifts and examine what revisions became necessary to our notions of their development. We begin with the apparent relationship of the 


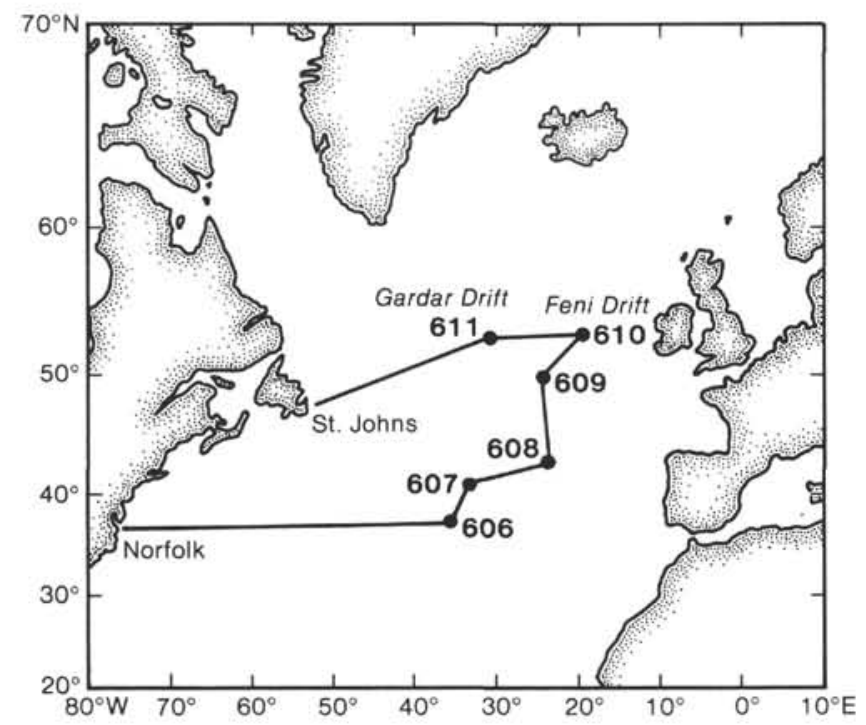

Figure 2. Location of sediment drift Sites 610 and 611 in the Leg 94 paleoclimate transect.

two drifts to the modern circulation. We then consider characteristics of the drifts and their environment that should be relevant to their sedimentation history. These characteristics vary in scale between (1) overall drift morphology versus the detailed morphology of the sediment waves; (2) the Tertiary stratigraphy of the drifts as established by drilling versus the detailed lithostratigraphy of the waves; (3) evidence of changes in sedimentary processes through time versus evidence of variability in the modern current regime over the drifts. In our discussion we attempt to identify factors that may be controlling deposition on the present wave fields and how they may have changed through time.

\section{MODERN CIRCULATION}

Figure 4 presents a generalized picture of the modern net near-bottom water circulation of the North Atlantic based upon an extensive literature review. The flow paths are more complex than is shown in the figure, as detailed in Dickson and Kidd (this volume) and by J. M. Rees (personal communication, 1985), and their variability may be an important factor in sedimentation, as will be discussed later. Relatively few long-term current meter data are available; the data of Dickson et al. (1984) are presently unique in their lengths of deployment. The location of sediment drifts as inferred from seismic profiles has had as much influence on the outlining of generalized circulation patterns (such as those in Fig. 4) as have actual current measurements (Hollister et al., 1978; Shor and Poore, 1979).

The overflow of Norwegian Sea water at several locations between Greenland, Iceland, and Scotland plays a major role in the overall Atlantic circulation. Dickson and Kidd (this volume), in their assessment of the oceanographic setting of Site 610 , recognize three principal sources of bottom water flow over the Feni Ridge:

- flows of Norwegian Sea Overflow Water (NSOW) across Wyville-Thompson Ridge
- detachment and southward recirculation of water from a northward flowing current along the European continental slope, North Atlantic Deep Water (NADW)

- a northward drift of deep water, presumed here to be Antarctic Bottom Water (AABW), which occupies the deepest layer of the Porcupine Abyssal Plain water column and which turns to the west and southwest as the Rockall Trough shoals towards the north Dickson and Kidd (this volume) conclude that the modern circulation at the southern end of Feni Ridge is dominated by the southerly sources of bottom water.

The influence of NSOW is more marked over Gardar Ridge (Site 611). McCave et al. (1980) described deep water flow in the Iceland Basin, showing that water from southerly sources (NADW and AABW) finds its way northwards over the Hatton sediment drift and then recirculates southwards when joined by NSOW south of the Iceland-Faeroes Ridge. McCave et al. suggest that NSOW is confined mainly between the northwestern-facing steep flank of Gardar Ridge and the Reykjanes Ridge but that it periodically spills down the southeastern slopes of the drift into the Iceland Basin. Site 611 is located just northeast of one of the sills through which NSOW spills into the Charlie Gibbs Fracture Zone and thence flows westwards into the western North Atlantic (Worthington, 1976).

\section{MORPHOLOGY OF THE DRIFTS}

Feni Ridge (Figs. 5 and 6) was first identified as a sediment accumulation against the southeastern flank of Rockall Plateau by Jones et al. (1970). North of $55.5^{\circ} \mathrm{N}$, the ridge consists of a wedge of sediment banked against the steep eastern slope of Rockall Plateau. The sediment drift extends as a longitudinal bathymetric feature for $520 \mathrm{~km}$. It begins at around $55.5^{\circ} \mathrm{N}, 14.5^{\circ} \mathrm{W}$, where it first becomes "detached" from the slopes of Rockall Plateau, and runs to around $52.5^{\circ} \mathrm{N}, 20.5^{\circ} \mathrm{W}$, at which point the crest intersects with the Isengard Ridge, also presumed to be a sediment drift (Roberts et al., 1979; Table 1, Fig. 1). The Feni Drift crest is sinuous; in its northern parts, crestal depths are less than $2300 \mathrm{~m}$, whereas the crest is $2800 \mathrm{~m}$ at the southeastern tip. The flanks extend eastwards towards Rockall Trough, down to $2900 \mathrm{~m}$ in the north and to $4000 \mathrm{~m}$ in the south. A "trough" exists between the ridge crest and the Rockall Plateau (Profiles b to f, Fig. 6). Dickson and Kidd (this volume) report a northward-flowing current in this "trough," a counter flow to the general circulation over the eastern flanks of the drift.

Sediment thicknesses to basement reach over $3.5 \mathrm{~s}$ (twoway traveltime) under the Feni Drift crest on multichannel seismic profiles (Masson and Kidd, this volume). Feni Drift as an anomalously thick sediment accumulation is recognized only in the upper 1.5 to $1.7 \mathrm{~s}(1500-1700 \mathrm{~m})$ of the records (Fig. 7) and is built on a regional reflector referred to as the "brown" reflector by Masson and Kidd (this volume).

The drift crest bifurcates on profiles to the southwest of Site 610 with a short branch between 53.5 and $54^{\circ} \mathrm{N}$ 
Table 2. Sediment waves on North Atlantic drifts.

\begin{tabular}{|c|c|c|c|c|c|}
\hline $\begin{array}{c}\text { Drift } \\
\text { name } \\
\text { (abbreviation) }\end{array}$ & $\begin{array}{l}\text { Apparent } \\
\text { wavelength } \\
(\mathrm{km})\end{array}$ & $\begin{array}{l}\text { Apparent } \\
\text { wave } \\
\text { height } \\
\text { (m) }\end{array}$ & $\begin{array}{l}\text { Wave } \\
\text { migration } \\
\text { from } \\
\text { profiles }\end{array}$ & $\begin{array}{l}\text { Range of } \\
\text { current } \\
\text { velocities } \\
(\mathrm{cm} / \mathrm{s})\end{array}$ & References \\
\hline $\begin{array}{l}\text { Bahama Outer Ridge } \\
\text { (BOR) }\end{array}$ & $2-3$ & $20-100$ & Upslope upcurrent & $10-20$ & $\begin{array}{l}\text { Flood, 1978, 1983; Kidd and } \\
\text { Roberts, } 1982\end{array}$ \\
\hline Bermuda Rise (BR) & $4-6$ & $20-30$ & Upslope upcurrent & 4-15 & $\begin{array}{l}\text { Embley et al., 1980; Flood, } \\
1983\end{array}$ \\
\hline $\begin{array}{l}\text { Blake Outer Ridge } \\
\text { (BBOR) }\end{array}$ & $2-6$ & $20-100$ & Upslope upcurrent & $5-20$ & $\begin{array}{l}\text { Flood, 1978, 1983; Tuchol- } \\
\text { ke, 1979; Kidd and } \\
\text { Roberts, } 1982\end{array}$ \\
\hline Bjorn Drift (BD) & \multicolumn{2}{|c|}{ No data } & - & $7-20$ & McCave et al., 1980 \\
\hline $\begin{array}{l}\text { Caicos Outer Ridge } \\
\text { (COR) }\end{array}$ & \multicolumn{2}{|c|}{$\begin{array}{l}\text { Sediment surface } \\
\text { undulations exist, } \\
\text { but no numerical } \\
\text { data }\end{array}$} & Upslope upcurrent & $5-15$ & $\begin{array}{l}\text { Embley et al., 1980; } \\
\text { Schneider and Heezen, } \\
1966\end{array}$ \\
\hline Corner Rise (CR) & \multicolumn{2}{|c|}{$\begin{array}{l}\text { Sediment waves and } \\
\text { undulations of } \\
\text { sediment surface } \\
\text { exist, but no } \\
\text { numerical data }\end{array}$} & Upslope upcurrent & $5-15$ & $\begin{array}{l}\text { McGregor et al., 1973; } \\
\text { Laine and Hollister, } \\
1981\end{array}$ \\
\hline Eirik Drift (ED) & 2 (ave.) & 50 (ave.) & Upslope upcurrent & $18-20$ & $\begin{array}{l}\text { Davies and Laughton, 1972; } \\
\text { Egloff and Johnson, } \\
1975\end{array}$ \\
\hline Feni Drift (FD) & $0.5-4.0$ & $23-50$ & $\begin{array}{l}\text { Upslope down- } \\
\text { current }\end{array}$ & $5-15$ & $\begin{array}{l}\text { Flood, 1978; Flood et al., } \\
\text { 1979; Kidd and Roberts, } \\
1982\end{array}$ \\
\hline Gardar Drift (GD) & $1.4-1.5$ & $28-35$ & None & $7-12$ & $\begin{array}{l}\text { Ruddiman, 1972; McCave et } \\
\text { al., } 1980\end{array}$ \\
\hline Gloria Drift (GRD) & 2 (ave.) & 50 (ave.) & $\begin{array}{l}\text { Upslope down- } \\
\text { current }\end{array}$ & 3-7 & $\begin{array}{l}\text { Davies and Laughton, 1972; } \\
\text { Egloff and Johnson, } \\
1975\end{array}$ \\
\hline $\begin{array}{l}\text { Greater Antilles } \\
\text { Outer Ridge } \\
\text { (GAOR) }\end{array}$ & \multicolumn{2}{|c|}{$\begin{array}{l}\text { Sediment waves and } \\
\text { furrows exist; data } \\
\text { in form of bottom } \\
\text { photographs only }\end{array}$} & Upslope upcurrent & $3-17$ & $\begin{array}{l}\text { Tucholke and Ewing, 1974; } \\
\text { Tucholke, 1975; Flood, } \\
1983\end{array}$ \\
\hline $\begin{array}{l}\text { Gulf Stream Drift } \\
\text { (GSD) }\end{array}$ & \multicolumn{2}{|c|}{$\begin{array}{l}\text { No numerical data- } \\
\text { turbidites rest on } \\
\text { erosional surface }\end{array}$} & $\begin{array}{l}\text { Westward, pro- } \\
\text { grading onto } \\
\text { Bermuda Rise }\end{array}$ & $9-10$ & Laine and Hollister, 1981 \\
\hline $\begin{array}{l}\text { Hatteras Outer } \\
\text { Ridge (HAT) }\end{array}$ & \multicolumn{2}{|c|}{$\begin{array}{l}\text { Sediment waves and } \\
\text { furrows exist but } \\
\text { no numerical data }\end{array}$} & Upslope upcurrent & $9.1-10$ & $\begin{array}{l}\text { Richardson, 1977; Tucholke } \\
\text { and Laine, } 1982\end{array}$ \\
\hline Hatton Drift (HD) & \multicolumn{2}{|c|}{$\begin{array}{l}\text { No measurable sedi- } \\
\text { ment waves exist }\end{array}$} & None & $6-24$ & McCave et al., 1980 \\
\hline $\begin{array}{l}\text { Hudson Drift } \\
\text { (HUD) }\end{array}$ & \multicolumn{2}{|c|}{$\begin{array}{l}\text { No sediment waves or } \\
\text { furrows exist }\end{array}$} & None & $10-20$ & Lowrie and Heezen, 1967 \\
\hline Isengard Drift (ID) & $0.3-0.5$ & $<20$ & $\begin{array}{l}\text { Upslope down- } \\
\text { current }\end{array}$ & $5-20$ & Flood, 1978 \\
\hline $\begin{array}{l}\text { Newfoundland Outer } \\
\text { Ridge (NOR) }\end{array}$ & \multicolumn{2}{|c|}{ No data } & - & $5-35$ & $\begin{array}{l}\text { Grant, 1972; Pastouret et } \\
\text { al., } 1975\end{array}$ \\
\hline Snorri Drift (SD) & $1-2$ & $20-30$ & - & & $\begin{array}{l}\text { Shor and Poore, 1979; } \\
\text { McCave et al., } 1980\end{array}$ \\
\hline
\end{tabular}

extending back to the slopes of Rockall Plateau. A more northern crestal bifurcation may be represented by a midtrough "high," recognized between 54 and $55^{\circ} \mathrm{N}$ (Fig. 5). This feature appears to be a later development than the main ridge, because it is characterized on seismic profiles as a positive accumulation above a reflector at approximately $0.7 \mathrm{~s}$ depth (the "yellow" reflector of Mas- son and Kidd, this volume). Bifurcation of drift crests is a feature that has been recognized on other drifts, including both the Bahama and Blake outer ridges (Kidd et al., 1980).

Gardar Ridge was first recognized by Jones et al. (1970) just east of the Reykjanes Ridge flank. It occupies much of the Iceland Basin. This sediment drift ex- 


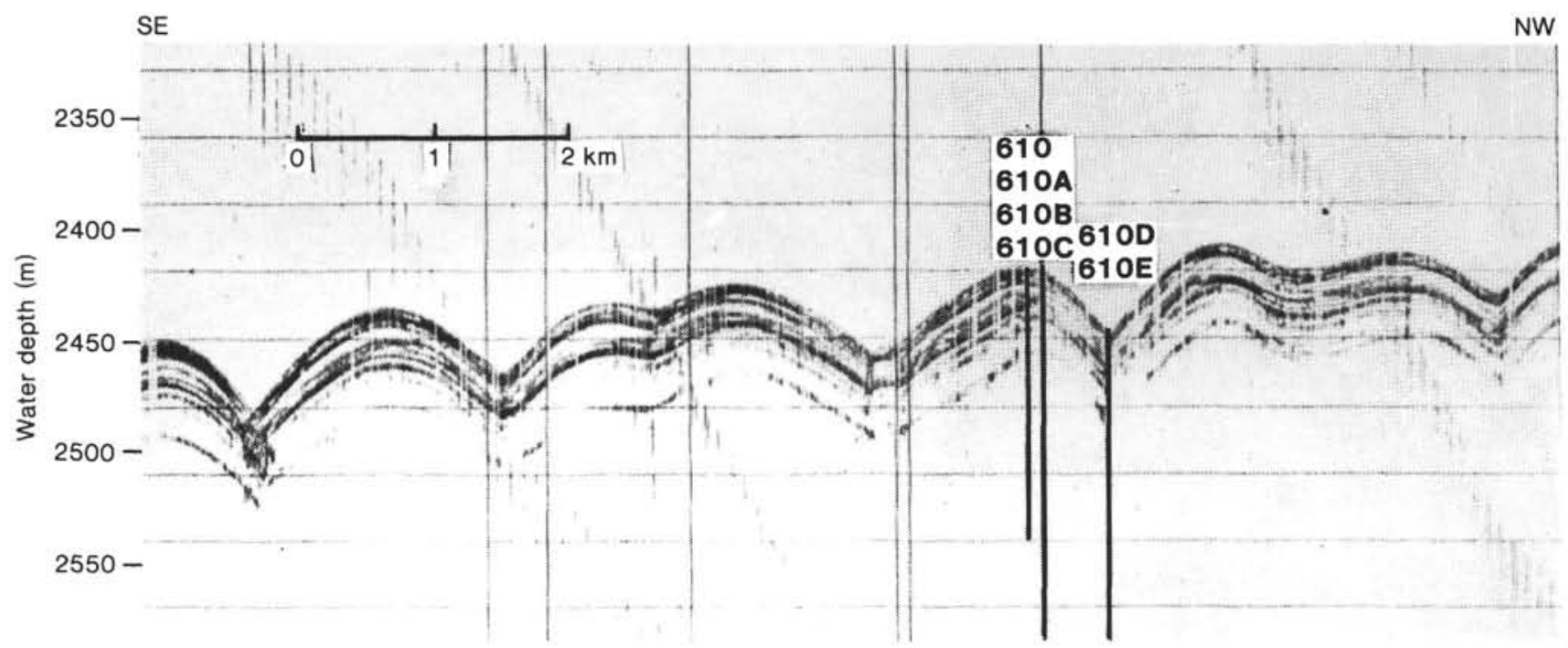

Figure 3. High-resolution seismic profile $(3.5 \mathrm{kHz})$ of the sediment waves on Feni Drift, illustrating location of crest and trough drilling at Site 610.

tends over $1000 \mathrm{~km}$ (Figs. 8 and 9) from $61.5^{\circ} \mathrm{N}$, where it begins as a prolongation of the Icelandic insular margin, to around $52.5^{\circ} \mathrm{N}$, where it abuts the topography of the Charlie Gibbs Fracture Zone. Site 611 is located at the extreme southern end in a lower flank setting. The Gardar Drift crest is sinuous and over much of its length is shallower than $3000 \mathrm{~m}$. The eastern flanks extend down to the Maury Channel, a mid-ocean turbidity current channel that follows the approximate axis of the Iceland Basin (Cherkis et al., 1973; Lonsdale et al., 1981).

Gardar Ridge sediment thicknesses vary from 1.3 to $1.6 \mathrm{~s}$ to acoustic basement (1300-1600 m thick). Because of the lack of extensive air-gun profiling coverage or of multichannel seismic profiles, it is unclear whether the ridge is anomalously thickened on any particular regional reflector (Fig. 10). Johnson et al. (1971) noted that a reflector traced at $0.6 \mathrm{~s}$ sub-bottom was subparallel to the drift crest surface. Discovery 134 air-gun seismic records used to locate Site 611 are more clear at deeper levels than the Figure 10 profile (see Site 611 report, this volume, fig. 12A). Acoustic basement on these records is defined by an irregular reflector that varies between 1.2 and $2.0 \mathrm{~s}$ sub-bottom (two-way traveltime) in the vicinity of the drill site. A deep, flat-lying reflector at around $1.0 \mathrm{~s}$ sub-bottom $(1000 \mathrm{~m})$ tops a sequence that appears to fill in the irregular basement relief. We presume that this reflector represents the base of the drift in this area.

The surface of Gardar Drift (unlike that of Feni Drift) is broken, especially in its northern parts, by a number of abyssal hills and seamounts. These represent original ridge-flank basement topography that has not yet been blanketed by sediment deposition (Johnson et al., 1971). Moating occurs around these features (Ruddiman, 1972), attesting to the effects of erosion and differential deposition by bottom water circulation. The abyssal hills on Gardar Drift make it difficult to ascertain whether bifurcation of the drift crest occurs. Analysis of individual east-west bathymetric profiles suggest that the crest of Bjorn Drift (Johnson et al., 1975), which is built against the upper flanks of the Reykjanes Ridge, may link with that of Gardar at around $56^{\circ} 30^{\prime} \mathrm{N}$ (Fig. 9).

Feni Drift is clearly the more coherent body of sediment, built directly against the eastern Rockall Plateau; Gardar Drift is much less constrained within the Iceland Basin. Gardar Drift appears to be an amalgamation of drift features, plastering the western Iceland Basin and Reykjanes Ridge. Nevertheless, the Feni and Gardar drift accumulations have similar thicknesses. Hatton Drift, located on the eastern margin of the Iceland Basin (Fig. 8), is similar to Feni Drift in size and structure and also has a similar thickness. These thickness similarities have led a number of workers to invoke a common time for initiation of drift development (Roberts, 1975; Shor and Poore, 1979; Miller and Tucholke, 1983), which will be discussed in a later section.

\section{SEDIMENT WAVE MORPHOLOGY AND STRUCTURE}

Both Feni and Gardar drifts are ornamented with largescale wavelike bed forms arranged in fields. Roberts and Kidd (1979) used long-range sidescan sonar (GLORIA II) to map sediment wave fields that occur along the eastern flanks of Feni Ridge (Fig. 11). Individual longitudinal wave crests could be followed for up to $26 \mathrm{~km}$. Wave heights ranged from 25 to $50 \mathrm{~m}$ and wavelengths from 1 to $4 \mathrm{~km}$. Along most of this survey of the ridge flank the wave fields were well developed. Roberts (1975), however, noted, on the basis of echo-sounder profiles, that the waves are sparse where Feni Drift is poorly developed and its east flank slopes gently, whereas large waves are found where the ridge is well developed and the east flank slopes steeply troughwards. Roberts and Kidd (1979) used a single, along-track $3.5-\mathrm{kHz}$ profile in conjunction with trends from their sonographs to interpret the apparent sense of migration of the waves (Fig. 11). They observed a general upslope migration over the entire eastern ridge flank, in agreement with observa- 


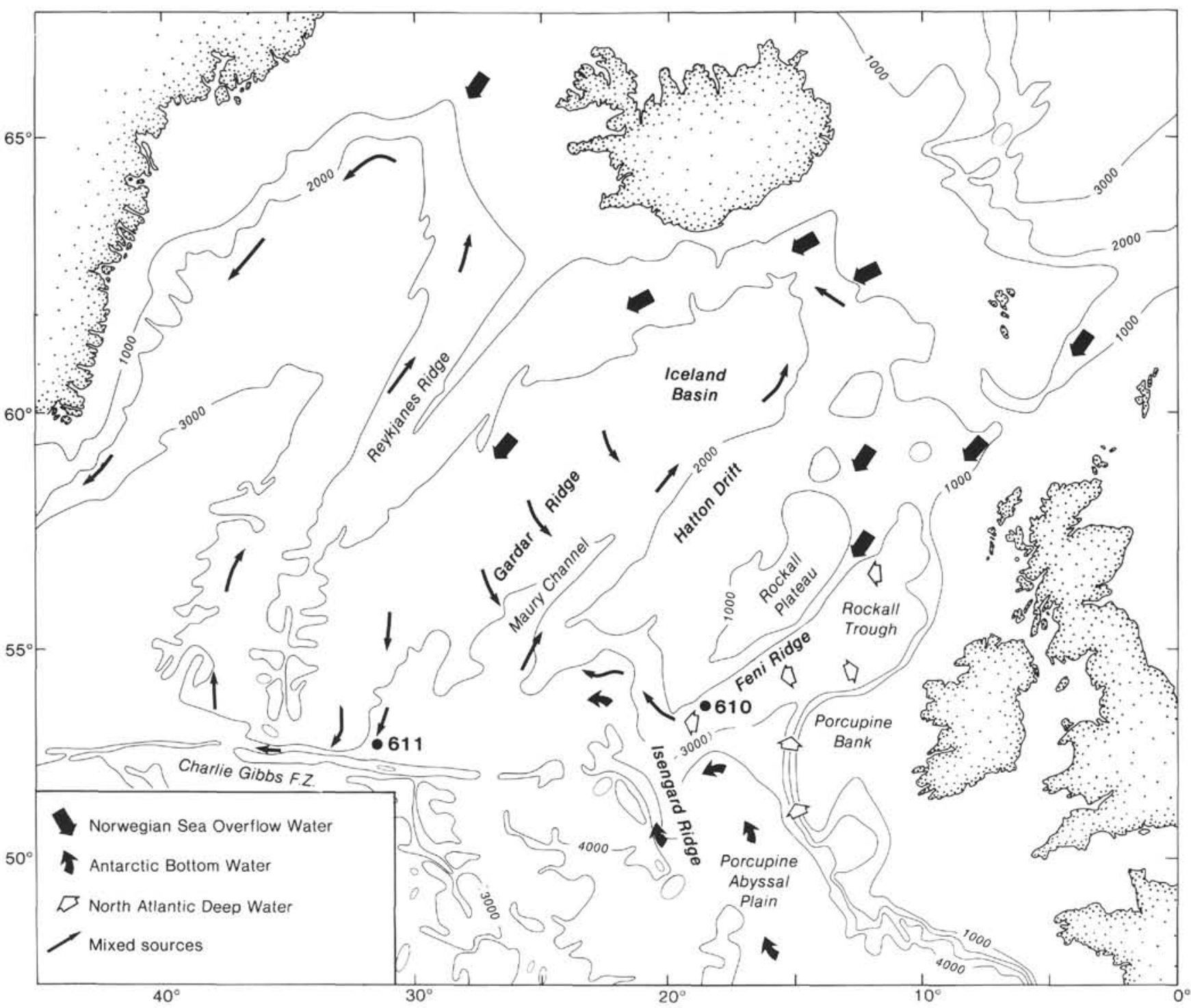

Figure 4. North Atlantic bathymetry and generalized bottom water circulation. Bathymetry in meters from Institute of Oceanographic Sciences Sheets 1 and 2 (Roberts et al., 1979; Laughton et al., 1984). Circulation primarily from Crease (1965), Lee and Ellett (1965), Worthington and Volkman (1965), Worthington (1976), Garner (1972), Ellett and Roberts (1973), McCave et al. (1980), Dickson et al. (1985), and Dickson and Kidd (this volume).

tions of wave migration on this and other drifts (Table 2), but they concluded that the migration was down-current, in contrast to migration with respect to mean current flow on most other drifts. Flood (1978) investigated two areas on the east flank of Feni Ridge (located at around $54^{\circ} 50^{\prime} \mathrm{N}, 15^{\circ} \mathrm{W}$ and around $56^{\circ} 30^{\prime} \mathrm{N}, 12^{\circ} 10^{\prime} \mathrm{W}$ ), using air-gun and $3.5-\mathrm{kHz}$ echo sounder profiling together with detailed near-bottom $4-\mathrm{kHz}$ deep-tow crossings; at the first survey area he found strong geophysical evidence of upslope wave migration, whereas at the second he found no migration at all.

During the transit to Site 610 we decided to relocate slightly the originally proposed ridge crest site to allow us to investigate an area where sediment waves had been identified from GLORIA data. GLORIA sonographs displayed subtle lineations that were interpreted as longitudinal wave crests close to this relocated site (Roberts and Kidd, 1979). Our subsequent Leg 94 echo sounder pro- files around the new Site 610 indeed showed sediment waves with heights of about $20 \mathrm{~m}$. But some misconceptions evolving from the earlier studies soon became clear.

On our initial site approach across the southern tip of the drift, we found no good examples of consistent wave migration on the air-gun or $3.5-\mathrm{kHz}$ records. Later, during our detailed presite survey (Fig. 12), we made a number of crossings over the sediment wave on which the acoustic positioning beacon had been dropped (Fig. 13). The varying trends of wave crests mapped from the GLORIA sonographs did not match all of the individual wave axes that could be traced track-to-track within the near-site survey area. The bathymetric map of the area around Site 610 (Fig. 14) shows our interpretation of the waves as irregular interfingered features arranged generally in an en echelon pattern. The subtle lineations, interpreted as continuous axes from the GLORIA sonographs, must represent an overemphasis by the system 


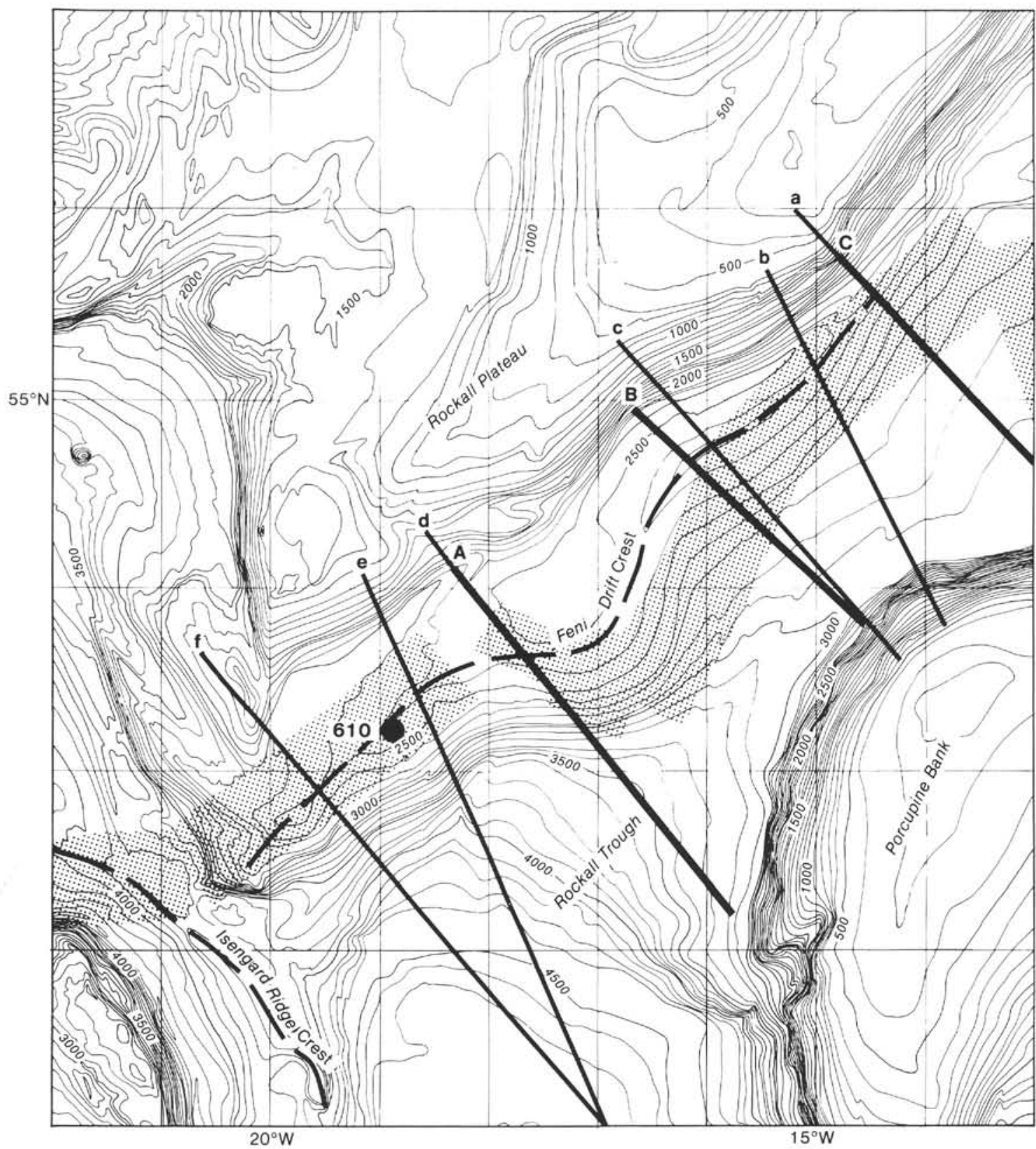

Figure 5. Feni Ridge bathymetry from Roberts et al. (1979). Bathymetric profiles identified as a through $\mathbf{f}$ are shown in Figure 6. Multichannel profiles A, B, and C are shown in Masson and Kidd (this volume); A appears as Figure 7 of this chapter. Stippled areas show the long-range sidescan sonar (GLORIA) coverage of Roberts and Kidd (1979).

of en echelon relief that is parallel to the track. This effect is an artifact of the GLORIA sonar system previously recognized by Belderson et al., (1972). The sonographs do appear, however, to provide accurate axial trends. The general trends varying between east-west and ENE-WSW visible in the GLORIA interpretations are evident in Figure 14.

In the immediate vicinity of Site 610 the sediment waves exhibit no well-pronounced sense of migration on the 3.5-kHz profiler crossings (Fig. 13). Attempts to use wave asymmetry and sequence thickening to determine apparent migration directions failed to indicate clear migration direction, despite several crossings on different headings (Fig. 12). We concluded that although there is no direct geophysical evidence for recent wave migration at the Feni drill site, migration might occur over other parts of Feni Drift.

Much less was known about sediment waves on the surface of Gardar Ridge. Short excursions onto the drift area from surveys conducted on the Reykjanes Ridge and Charlie Gibbs Fracture Zone provide the only GLORIA plan-view images (Jacobs, this volume). Near Site 611, surveys run by Discovery, Vema, and Challenger (Fig. 15 ) allowed the tracing of generalized trends for the larger, most distinctive waves. It was clear from $3.5-\mathrm{kHz}$ profiles, however, that the waves are considerably more variable in size and shape than those in the Feni Ridge wave fields (Fig. 16). Apparent wave heights average $10 \mathrm{~m}$ 


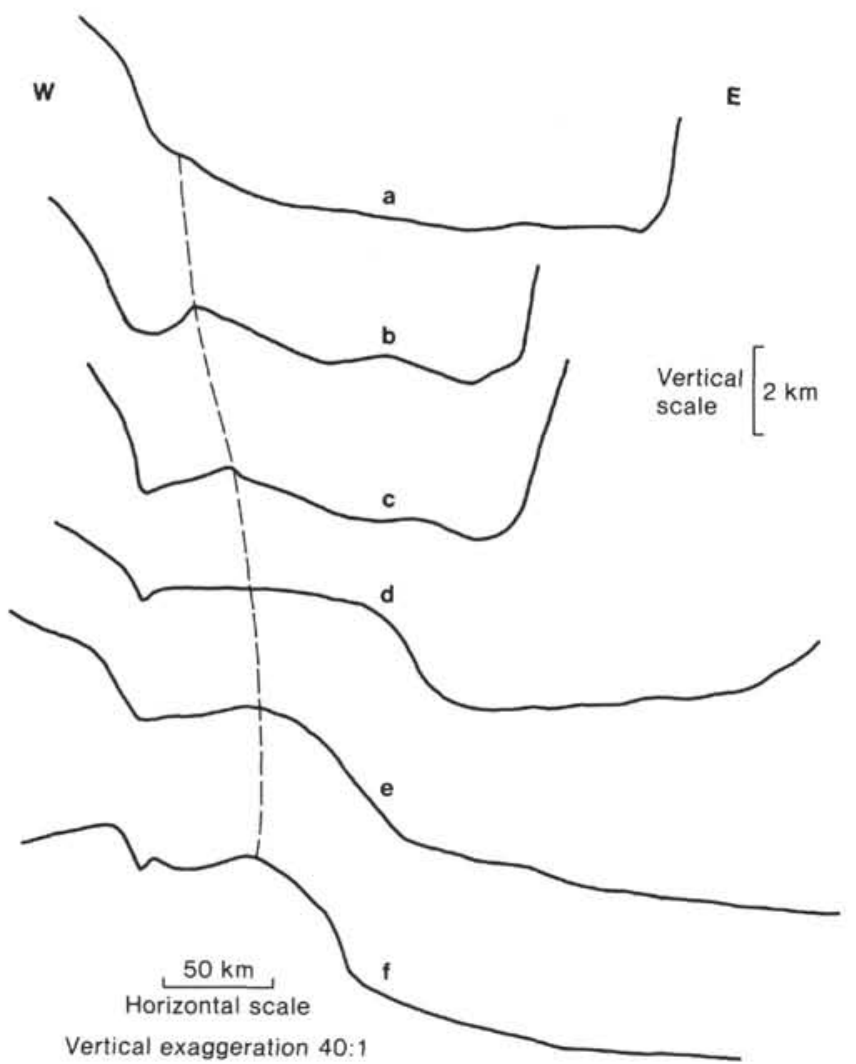

Figure 6. Sequence of west-east bathymetric profiles based upon original echo-sounder records over Feni Ridge, northern Rockall Trough to the Porcupine Abyssal Plain (from Masson and Kidd, this volume).

and wavelengths $1.5 \mathrm{~km}$. Wave crests traced on nearby GLORIA sonographs are continuous over $6 \mathrm{~km}$. Sediment waves on Gardar Drift show no evidence of migration. On air-gun profiles the largest sediment waves are located over basement highs, which suggests that at least some of the waves originated over irregularities in basement relief. In Figure 16 (and in other illustrations in the Site 611 report, and in Jacobs, this volume) the most dis- tinctive wave crests are correlated across several air-gun and $3.5-\mathrm{kHz}$ profiles near Site 611 so that there appears to be only one major wave axis trend near this site (ENEWSW). Our results from more detailed surveys near Site 610 , over less variable wave relief, had already cautioned against reliance on such correlations. Ship maneuvers during operations to offset drill holes at Site 611 (see Site 611 report, this volume) aptly emphasized this morphological variability.

For comparison we plotted histograms of apparent wave height and length for both sites (Fig. 17). The data represent apparent values, as they are for crossings oblique to wave crests. Frequently, values from more than one crossing of the same wave are plotted. Typically over one hundred crossings of wave axes were made during the survey of an area covering $4630 \mathrm{~km}^{2}$, such as in Figure 15 . The information is of value in comparing these waves with data available from other wave fields (Table 2). Most waves ornamenting sediment drifts are closely comparable in size: only those on the Blake and Bahama outer ridges are significantly larger. Sediment waves near the crest of Feni Ridge have an average apparent height of around $23 \mathrm{~m}$ and an average apparent wavelength of 2.2 $\mathrm{km}$. The wave upon which our deep hole was drilled was approximately $28 \mathrm{~m}$ high and had a 1.4-km wavelength. The Gardar waves have very similar wave heights but are significantly more limited in range of wavelengths. The wave drilled at Gardar was approximately $35 \mathrm{~m}$ high and again $1.4 \mathrm{~km}$ in wavelength.

We cannot show a consistent link between the sediment wave fields at Sites 610 and 611 and bottom water flow. Variability in wave trend and shape and a lack of apparent migration on profiles characterize Site 610 where our most detailed morphological information is available. Variability in wave size and shape with again no apparent migration characterize Site 611 , and data on wave trends are suspect. We have good near-site bottom current measurements only on Feni Drift (Dickson and Kidd, this volume), and these are taken $45 \mathrm{~m}$ above bottom. One mooring set on the northwestern side of the ridge axis detected a steady northeastward current of 3.7

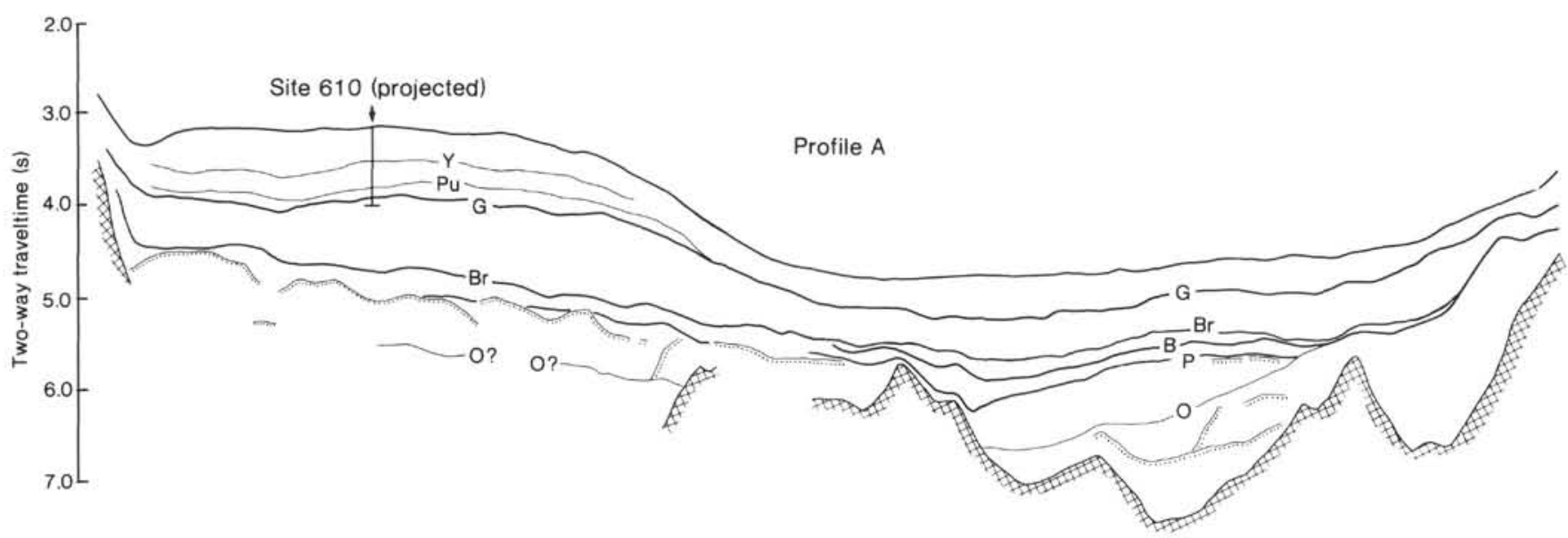

Figure 7. Interpretive line drawing of multichannel line $\mathrm{A}$ across southern Rockall Trough and Feni Ridge from Masson and Kidd (this volume) (see Fig. 5 for location). The color-coded reflectors are $\mathrm{Y}=$ "yellow"; $\mathrm{Pu}=$ "purple"; $\mathrm{G}=$ "green"; $\mathrm{Br}=$ " brown"; B = "blue"; $\mathrm{P}=$ "pink"; $\mathrm{O}$ $=$ "orange". Stippled discontinuous reflectors are presumed sills. Basement is cross-hatched. 


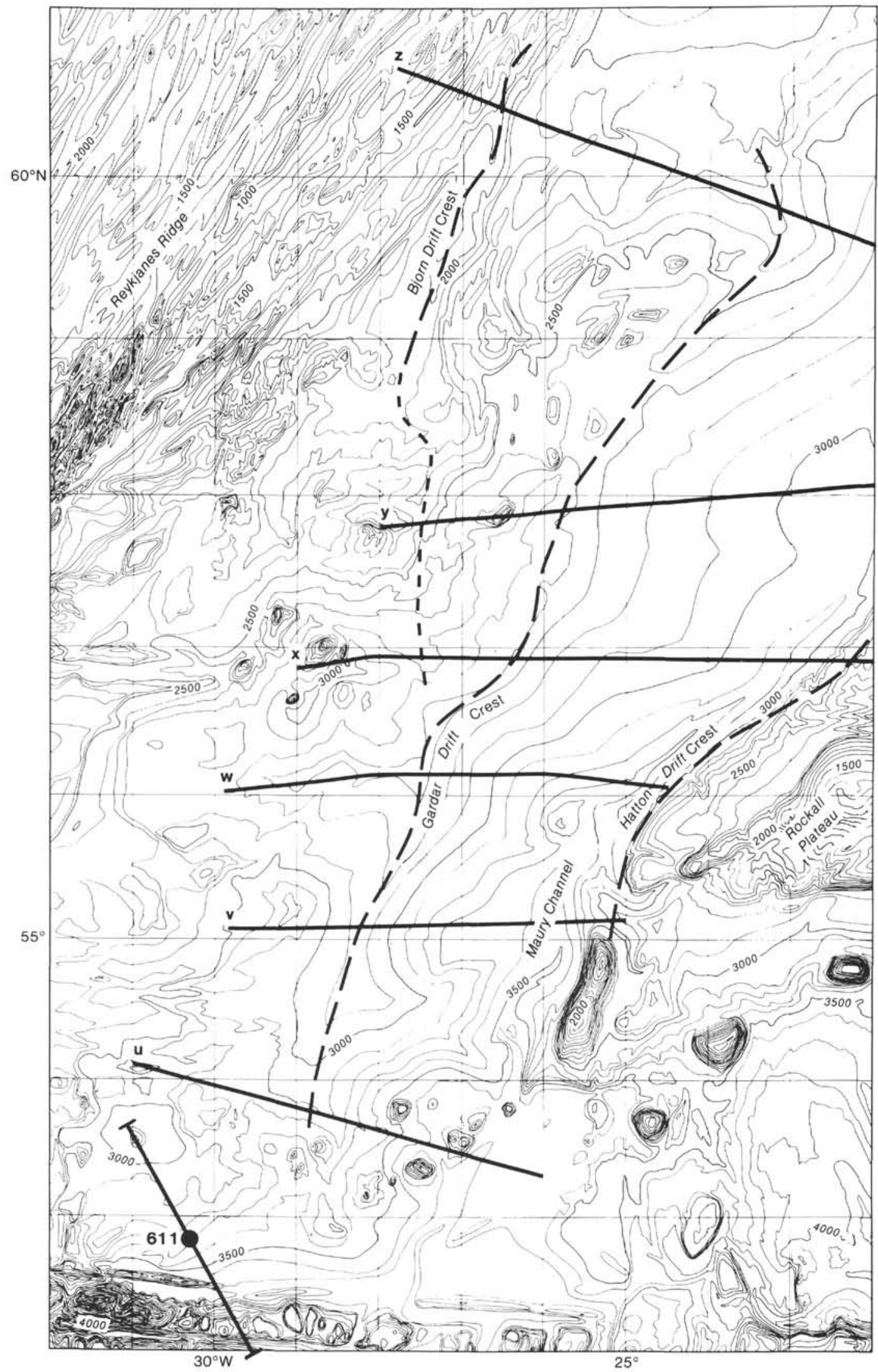

Figure 8. Gardar Ridge bathymetry from Laughton et al. (1984). Bathymetric profiles identified as $\mathbf{u}$ through $\mathbf{z}$ are shown in Figure 9. Line with end-bars through Site 611 locates the air-gun profile shown in Figure 10. Bjorn Drift crest may join with Gardar Drift as shown, see profiles $\mathbf{y}$ and $\mathbf{x}$. 


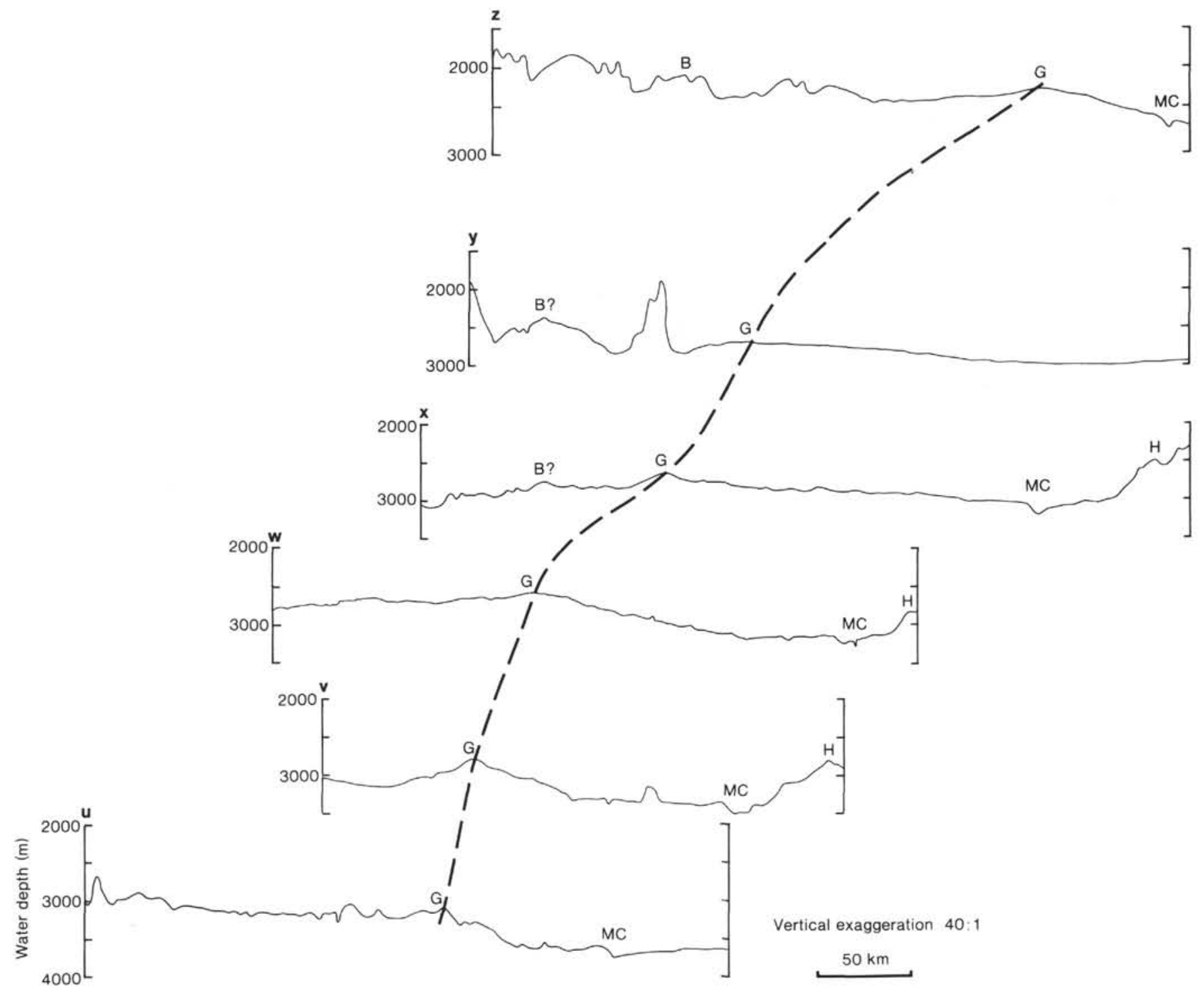

Figure 9. Sequence of west-east bathymetric profiles based upon original echo-sounder records over Gardar Ridge, northern Iceland Basin to Charlie Gibbs Fracture Zone. G = Gardar Drift crest; B = Bjorn Drift crest; MC = Maury Channel axis; H = Hatton Drift crest.

$\mathrm{cm} / \mathrm{s}$ whereas another, on the same southeastern flank of the drift as Site 610 but downslope at around $3200 \mathrm{~m}$, detected a vigorous southwestward flow of around 5.9 $\mathrm{cm} / \mathrm{s}$. Dickson and Kidd (this volume) show that the northeasterly "reverse" flow, occupying the low between the Feni Ridge crest and the flanks of Rockall Plateau, and the general southwestward flow over the eastern flanks of the drift form a stratification in the water column with the division at 2500 to $2600 \mathrm{~m}$ depth. They suggest that variation in depth of this boundary would allow it to intersect the seafloor at the level of Site 610 , which might explain the complex interplay of wave trends observed at the site.

\section{DRIFT STRATIGRAPHY}

The major stratigraphic finding of our Leg 94 drift drilling was the dating of the regional reflector in the Feni Ridge area, previously recognized as the "R4" reflector by Roberts (1975) and Roberts et al. (1981) and called the "Challenger" reflector by Dingle et al. (1982). The reflector drilled is early Miocene in age and thus the upper sequence at Feni Drift is clearly much younger than predicted by Roberts (1975), who thought it to be a late Eocene-early Oligocene reflector.

Masson and Kidd (this volume) relate the drilling results to multichannel profiles across Feni drift (Fig. 7). They show that the reflector drilled at Site 610 (their early Miocene "green" reflector) represents only a middrift event. This is the "R2" reflector identified elsewhere (Miller and Tucholke, 1983). The reflector at the base of the drift sequence (the "brown reflector of Masson and Kidd, this volume) indicates the true initiation of drift sedimentation in the area; the "brown" reflector appears to correlate with that identified as "R4" by Miller and Tucholke (1983) and with the "Charcot" reflector of Dingle et al. (1982), and has been dated as late Eocene to early Oligocene (Table 3). Many authors have suggested that a major change occurred in North At- 
Gardar Ridge

Charlie Gibbs Fracture Zone

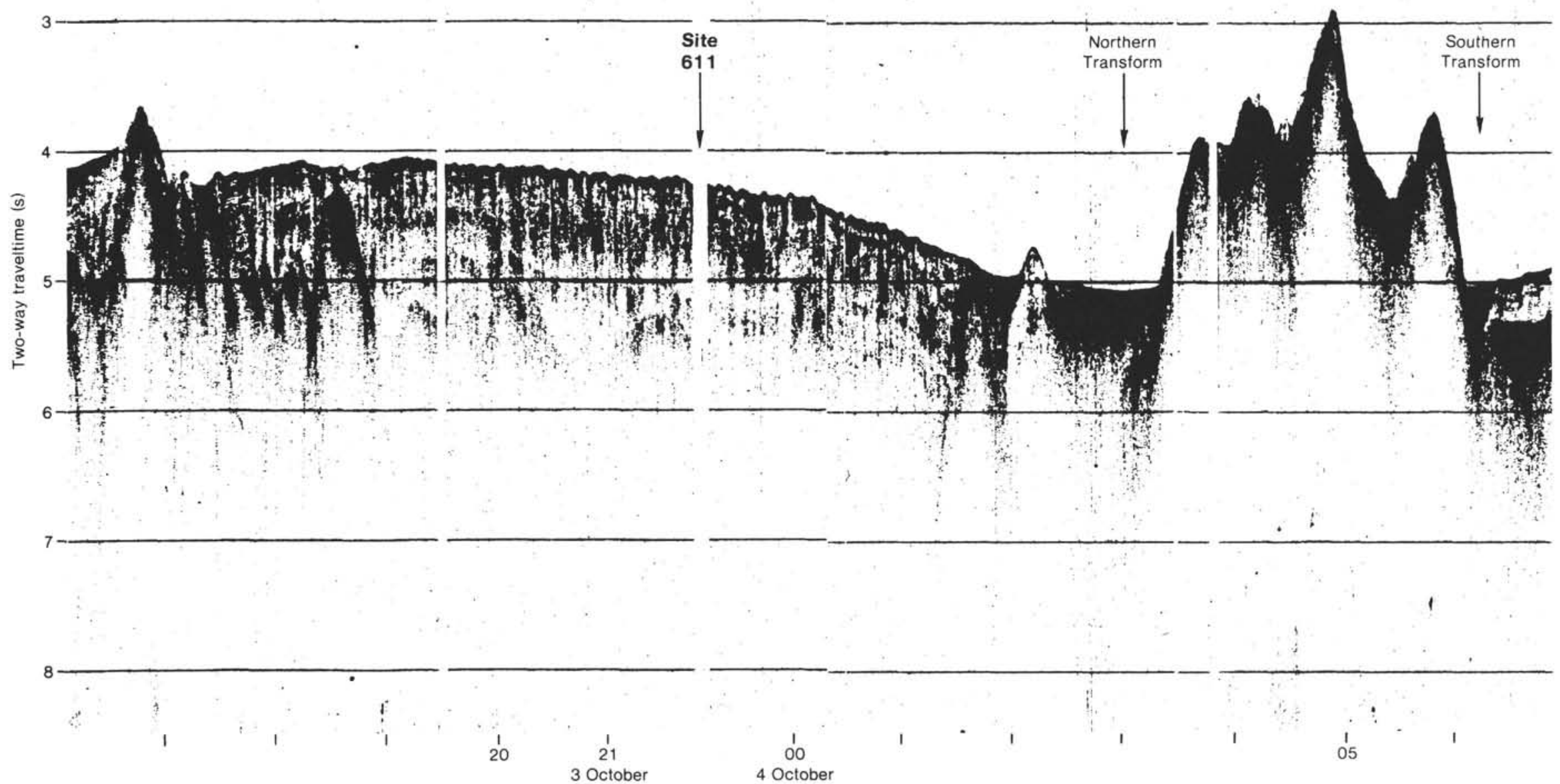

Figure 10. Air-gun seismic profile through Site 611 crossing southern tip of Gardar Ridge (note sediment waves) and transform features of Charlie Gibbs Fracture Zone; for location see Figure 8. 


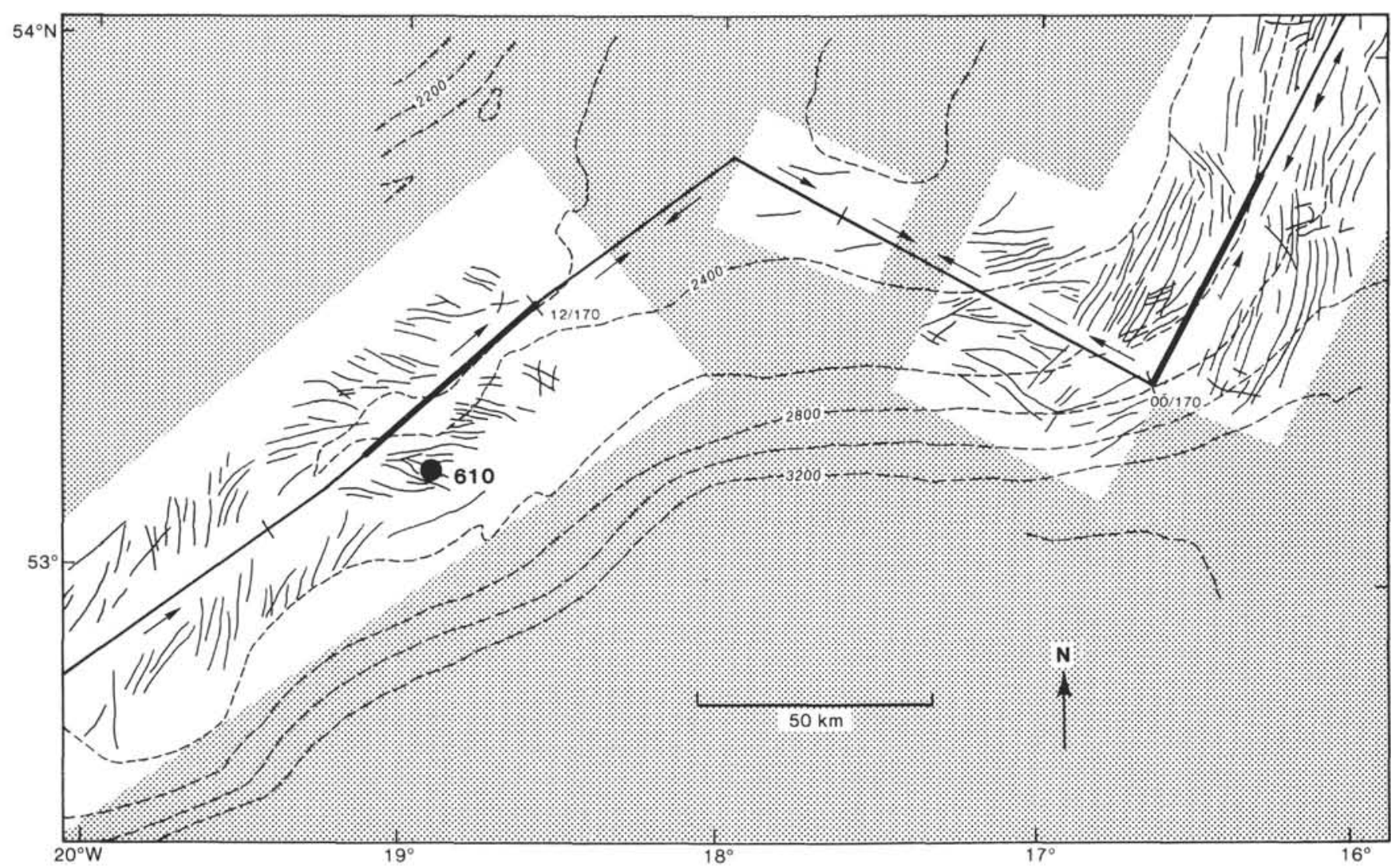

Figure 11. Interpretation of sediment wave axial trends on Feni Drift in the vicinity of Site 610 (from Roberts and Kidd, 1979) based upon GLORIA long-range sidescan sonar coverage (unstippled areas). Arrows represent their interpretations of wave migration from an along-track $3.5-\mathrm{kHz}$ profile.

lantic circulation in the late Eocene to early Oligocene (summaries in Miller, 1982; Stow and Holbrook, 1984).

The cause of the rapid increase in seismic velocity over the interval from 625 to $675 \mathrm{~m}$ sub-bottom at Site 610 , the "green" reflector of Masson and Kidd (this volume), is an increase in hardness resulting from compaction and silica diagenesis of uppermost lower Miocene sediments. No lithologic evidence of a hiatus was found, but the sedimentation rate curve at this level shows a scatter of paleomagnetic and biostratigraphic data that may be indicative of some change in deposition rate (Fig. 18). Only the upper $200 \mathrm{~m}$ of this sedimentation rate curve has the high-resolution, combined paleomagnetic and biostratigraphic control that is characteristic of other Leg 94 time versus depth curves (Baldauf et al., this volume). Characte.istics of the biogenic silica component of the sediments suggest that a significant oceanographic event occurred at this time, which only later became overprinted by compaction and diagenesis (Baldauf, this volume; Dolan, this volume; Miller et al., this volume; Thomas, this volume). Miller (1982) considered his "R2" to reflect a short interval of intensified abyssal circulation. Except for the absence of a clear hiatus at Site 610 , these results do not disagree with his conclusion. A hiatus may indeed occur elsewhere on the drift because there is truncation of underlying reflectors by the "yellow" reflector (Fig. 18) southeast of Site 610 (Masson and Kidd, this volume).
Whereas the "green" reflector is regional in the Rockall Trough, the "yellow" and "purple" reflectors appear to be confined to the drift sedimentary sequences. The seismic velocity jump causing the "purple" reflector (Fig. 18) occurs in a spot-cored interval at Site 610 (510-550 $\mathrm{m}$ sub-bottom), and its origin remains unclear. It is tentatively dated as mid-middle Miocene. Masson and Kidd's "yellow" reflector (Fig. 18) is tied to a velocity increase between 300 and $350 \mathrm{~m}$ sub-bottom at Site 610 . No lithological differences were detected at this level other than an increased percentage of reworked foraminifers. This reflector may relate to a period of change in accumulation rate because in Figure 18 there is another apparent offset in the time versus depth curve. Keigwin et al. (this volume), on isotopic evidence, note a condensed interval at around $290 \mathrm{~m}$ sub-bottom. The occurrence of two reflectors within $100 \mathrm{~m}$ of one another allows considerable room for misidentification of "purple" versus "yellow" reflectors on low-resolution single-channel air-gun records. This makes it difficult to tie either to specific tectonic events affecting the region in the early and middle Miocene, such as subsidence events at the Wyville-Thompson Ridge (Roberts et al., 1983).

Masson and Kidd (this volume) correlate the "yellow" reflector with "R1" of Miller (1982), which the latter author considers is of local extent in the Northeast Atlantic. On the other hand, its late late Miocene age 


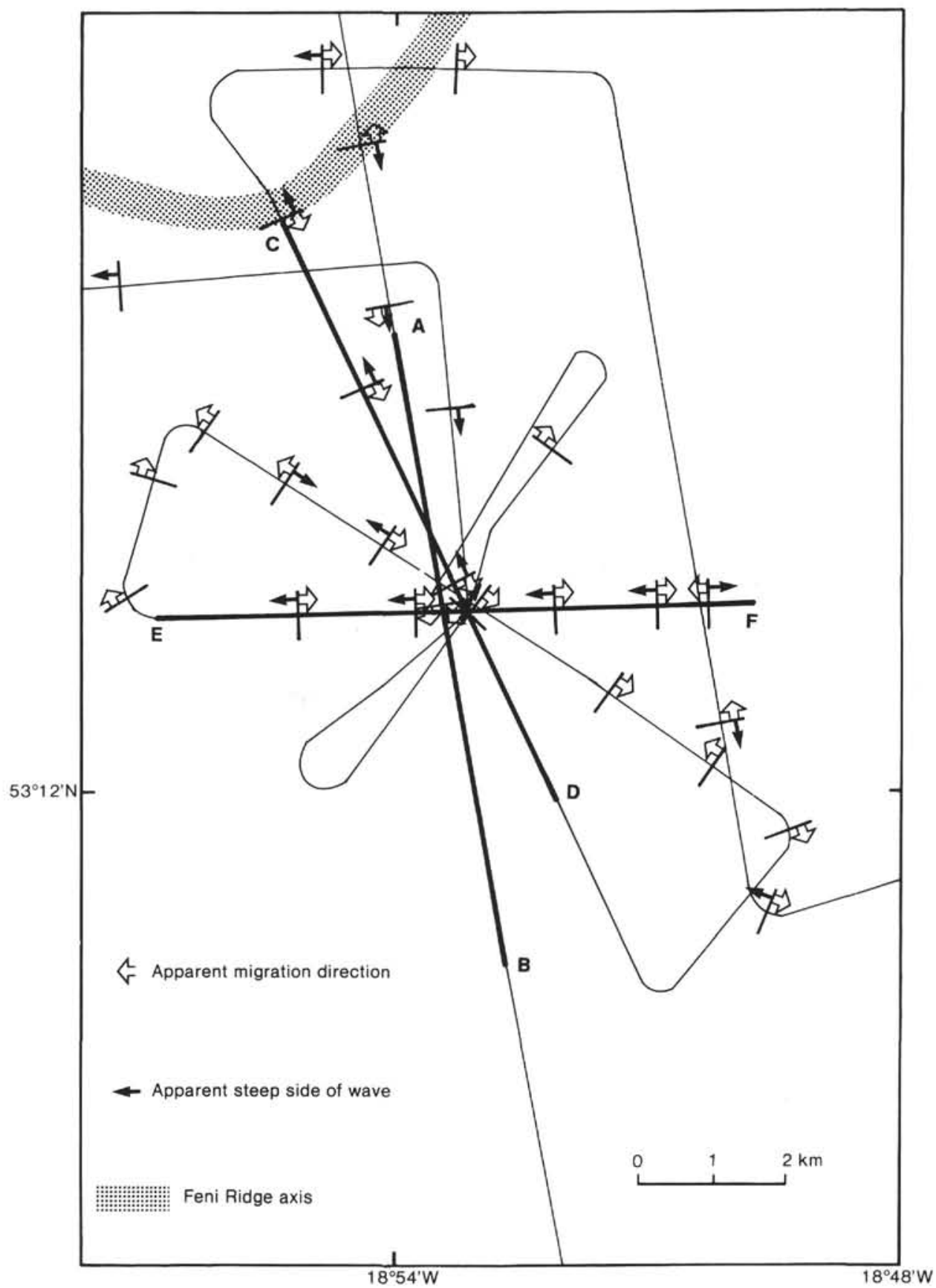

Figure 12. Glomar Challenger $3.5-\mathrm{kHz}$ and air-gun seismic survey of the area around DSDP Site 610 . Broad arrows indicate interpretations of apparent wave migration directions for the individual sediment waves. Narrow arrows show apparent steep sides ("facing") of waves. No consistent wave migration direction is indicated. Profiles A-B, C-D, and E-F are illustrated in Figure 13.

suggests a link with the isolation of the Mediterranean in Messinian time. There is a body of physical oceanographic and geologic evidence for a modern eastern boundary current along the European Margin (Dickson and Kidd, this volume; McCave et al., 1980; Gardner and Kidd, 1983; Stow and Holbrook, 1984). Gardner and Kidd (in press) note that this current flow is augmented presently by part of the Mediterranean Sea Outflow Water that passes along the northern Gulf of Cadiz and turns northwards along the Iberian continental margin; these authors reinterpreted a widespread regional reflector off Spain and Portugal that was drilled at DSDP Site 398 (Sibuet, Ryan, et al., 1979). They related the reflector to cutoff of the Mediterranean water that had occupied the upper margin slopes. This cutoff during the Messinian brought about a period dominated by downslope sedimentary processes, but was followed by a sudden return to along-slope bottom current conditions. Similar changes might have also occurred in the Rockall Trough.

Because the only lithologic change (reworked foraminifers) identified at about the level of the "yellow" re- 


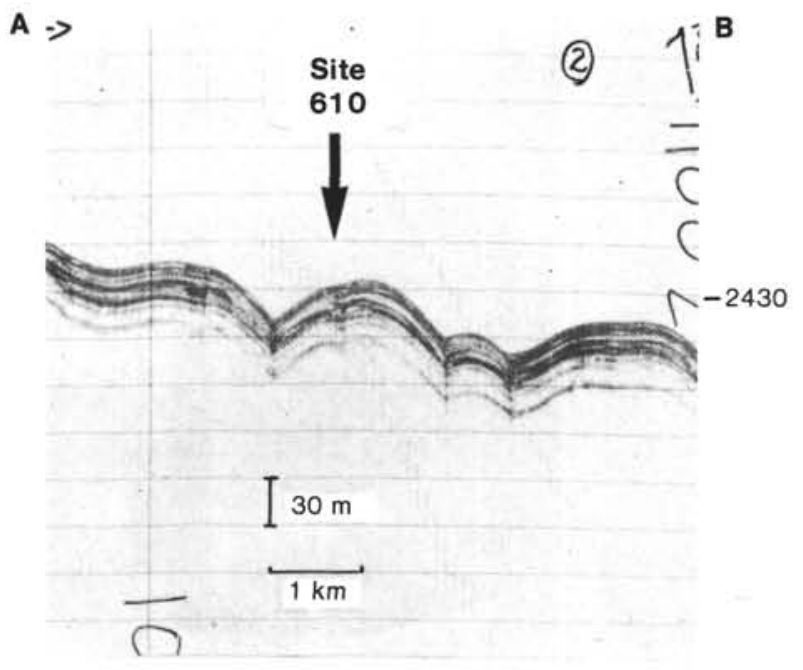

C

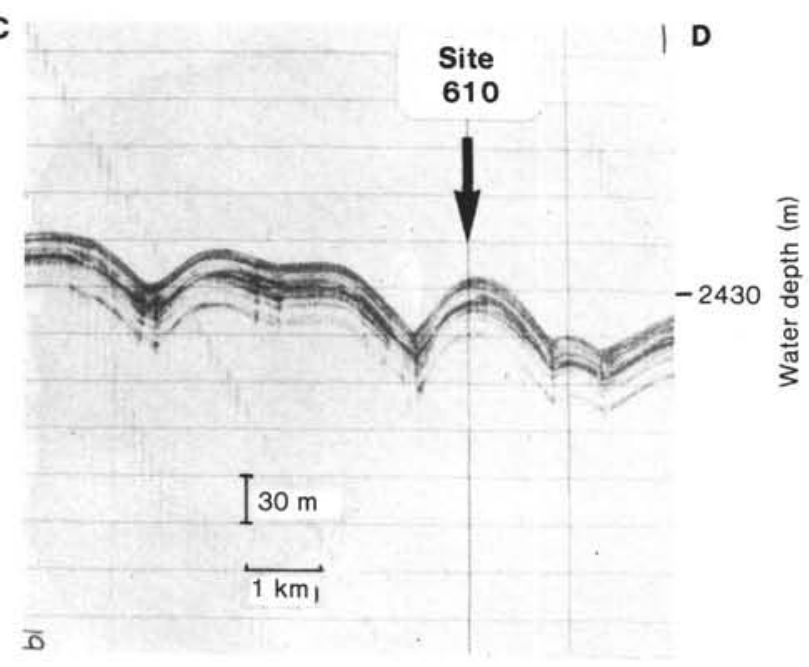

$\mathbf{E}$

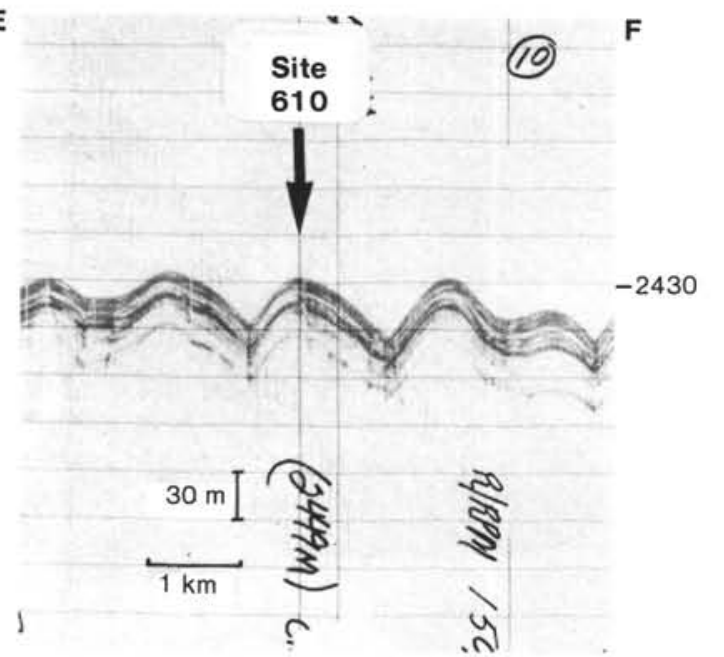

Figure 13. $3.5-\mathrm{kHz}$ sounder profiles across the sediment wave drilled at DSDP Site 610.

flector at Site 610 appeared to suggest increased bottom current strength (winnowing), but no hiatuses had been reported in some of the Goban Spur or Biscay drill sites, Masson and Kidd (this volume) were reluctant to sug- gest a Mediterranean link for this reflector. They concluded that it was tied to intensification of Norwegian Sea Overflow. More recent biostratigraphic comparison of unconformities at the Goban Spur and Biscay drill sites (I. Pearson, personal communication, 1985) suggests that a regional hiatus may indeed be present, which in our opinion reopens the question whether the isolation of the Mediterranean had a recognizable effect on sedimentation as far north as Feni Drift: cutoff of Mediterranean bottom waters might indeed have allowed NSOW to dominate over Feni Drift during this period.

The lack of multichannel seismic profiles in the Site 611 area and our experience with reinterpretation of single-channel records at Site 610 deters us from a major re-examination of the seismic stratigraphy of Gardar Drift. It seems clear that we drilled a sequence equivalent to part of Masson and Kidd's post-"green"-reflector sequence (Table 3).

\section{SEDIMENT WAVE LITHOSTRATIGRAPHY}

Acoustically defined sediment waves occupy only the upper parts of the seismic sequences on Feni and Gardar drifts. They are best illustrated on the Glomar Challenger air-gun profiles around Site 610 , where they characterize the upper 0.1 to $0.15 \mathrm{~s}$ of the sequence and show an apparent increase in amplitude upwards (fig. 6 in Masson and Kidd, this volume). On Gardar Drift the waves are confined to the upper $0.2 \mathrm{~s}$ of water-gun profiles over Site 611 (Site 611 report, fig. 12B). The Leg 94 strategy of drilling offset holes in the sediment wave fields was designed to provide detail on the stratigraphy, lithologies, sedimentary structures, and sedimentation rates in two supposedly distinct drift environments.

On Feni Ridge a sediment wave crest that was traceable laterally for several kilometers was selected at 2417 $\mathrm{m}$ water depth. Four holes were continuously cored (610, $610 \mathrm{~A}, 610 \mathrm{~B}$, and $610 \mathrm{C})$, the first of which was the deep hole extending to the lower Miocene at $690 \mathrm{~m}$ sub-bottom (Fig. 3). Two holes (610D and 610E) were located in the adjacent trough at $2445 \mathrm{~m}$ water depth (Fig. 13) approximately $0.6 \mathrm{~km}$ WNW of the crestal holes (vertical offset $28 \mathrm{~m}$ ). Continuous coring in these holes extended only to the upper Pliocene.

On the Gardar Drift, the wave crest holes were located in $3203 \mathrm{~m}$ of water, and the trough holes were offset to the southwest by approximately $1 \mathrm{~km}$ in $3227 \mathrm{~m}$ of water (vertical offset $24 \mathrm{~m}$ ). The drilling strategy was slightly altered at Site 611 . It was decided that a detailed sampling of both crest and trough holes was necessary to verify the hypothesis that sedimentation rate curves at the two locations were significantly different, and might show wave migration. Both crest $(611,611 \mathrm{~A}, 611 \mathrm{D}$, and $611 \mathrm{E})$ and trough (611B and 611C) holes were sampled continuously to the lower Pliocene. At the crest the drilling terminated at $244 \mathrm{~m}$ sub-bottom in the lower Pliocene, whereas in the trough discontinuous sampling was continued to the middle Miocene at $512 \mathrm{~m}$ sub-bottom.

Hill (this volume) provides a detailed summary of the sedimentary characteristics of the drift lithologies as sampled in this multihole approach. The sequences at the two sites are essentially similar in composition, compris- 


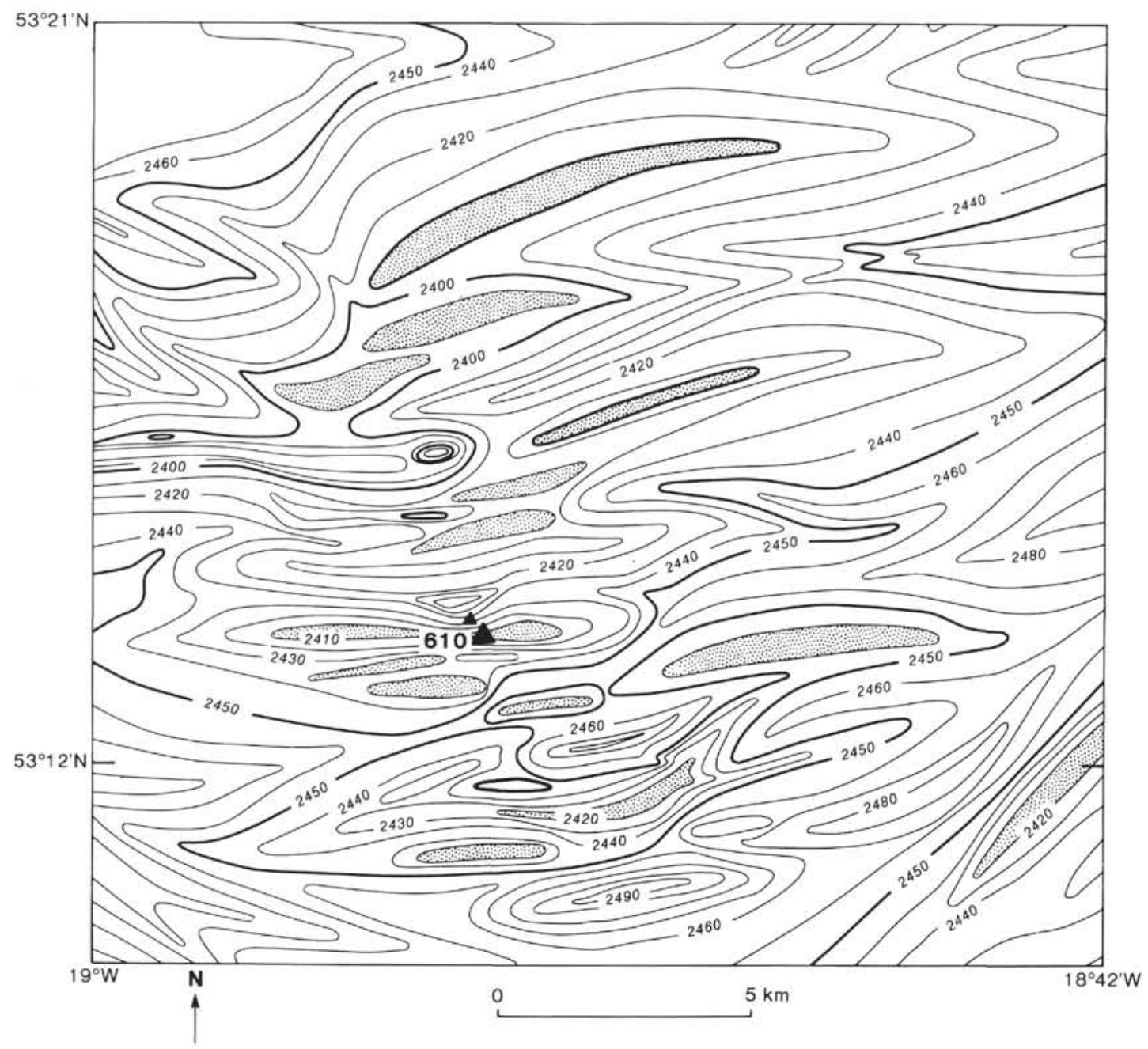

Figure 14. Detailed bathymetric map of the immediate vicinity of DSDP Site 610. Major sediment wave crests are stippled. Large triangle indicates wave crest Holes 610, 610A, 610B, 610C. Small triangle locates offset wave trough Holes $610 \mathrm{D}$ and $610 \mathrm{E}$.

ing interbedded nannofossil ooze and calcareous marl or mud throughout the upper Pliocene and Quaternary glacial cycles, and nannofossil ooze in the Miocene and lower Pliocene preglacial sections. Compared with the Feni Drift sediments, lithologies in the Gardar holes are characterized by (1) a greater abundance of volcanogenic material from Icelandic sources (Eggers and Ehrlich, this volume) and (2) a relatively high biogenic silica content in the nannofossil ooze intervals, resulting from the location of Site 611 relative to subpolar areas of high silica productivity. The sequences on both drifts are extensively burrowed, mainly by Zoophycos and Planolites; burrows are most visible at the main lithological boundaries. In some calcareous mud beds of the glacial sequence, gravel- and sand-size ice-rafted erratic material is concentrated in discrete layers. Despite intensive examination of the cores aboard ship and thorough shorebased X-radiograph analysis, we found few primary sedimentary structures other than some vague, isolated, horizontal laminations. In addition, a study of the magnetic fabric of the sediments found no clear evidence of current-controlled deposition (Hailwood et al., this volume), although this may be due either to the weak mag- netic signature of the samples or to postdepositional bioturbation.

Grain-size analyses show that the sediments of the drift sequences are characteristically bimodal with a fine mode around $10 \mu \mathrm{m}$ presumed to represent mainly coccolith content, and a coarser "foraminifer" mode at around $110 \mu \mathrm{m}$. Bulk grain size changes significantly over transitions from calcareous mud to nannofossil ooze (Hill, this volume). These changes are generally not in phase with variations in the sedimentary components and so cannot be related simply to differences in sediment supply caused by glacial-interglacial climate fluctuations. The grain size variations could have been caused by dissolution of foraminiferal tests, by changes in foraminiferal productivity, or by sorting by currents. Current-sorting might appear the most plausible process, but it cannot explain the complete absence of foraminiferal tests at certain levels in the sequence, especially when laminations indicative of dynamic sorting are absent.

Because of the striking visibility of the glacial-interglacial cycles in all but the deepest of the drill holes, we were able to examine lithostratigraphic correlations within the wave fields in detail. Surprisingly little thickness varia- 


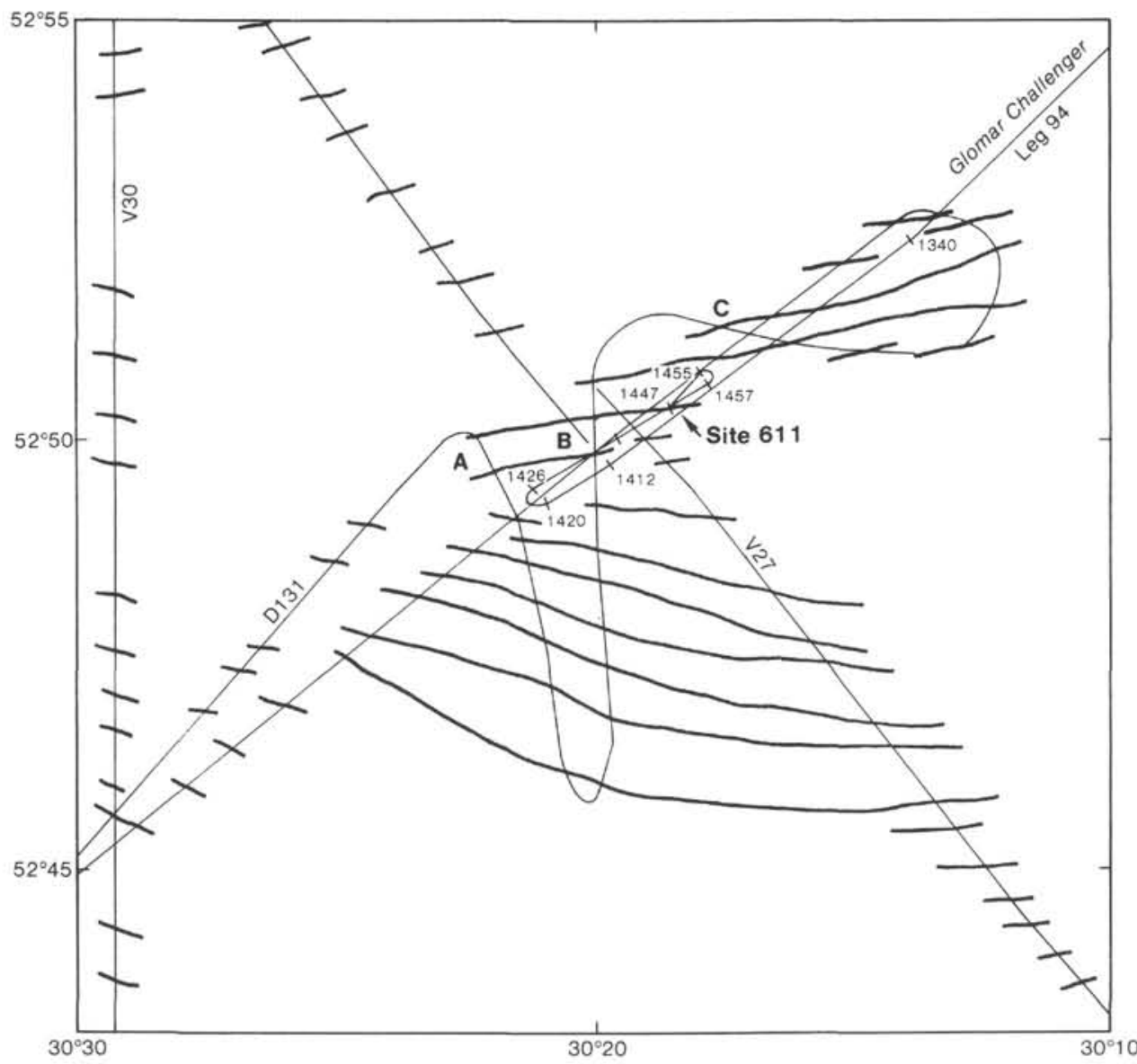

Figure 15. 3.5-kHz and air-gun seismic surveys around DSDP Site 611 with attempts to correlate wave crests shown in bold lines. D131 = Discovery track, Cruise 131 (see Fig. 16); A, B, and C represent turns in this track.

tion is apparent between wave crests and troughs on both drift sites (Figs. 19 and 20 and volume frontispiece). Significantly, thickness variations between holes on a crest or within a trough are frequently as much as between crest and trough. Ruddiman et al. (this volume) are able to explain most thickness variation as due to core disturbance and mis-sampling by the hydraulic piston coring (HPC) system. In the preglacial sequence of nannofossil oozes we lacked sufficient marker horizons to make similar hole-to-hole correlations. As is discussed below and in the Site 611 report (this volume), evidence from sediment accumulation rate curves suggests some differences here that related to sediment wave migration. One inference that can be made from the striking visual correlations in the upper parts of the drift sequences is that hiatuses are probably absent between the drill holes and the sequences represent essentially continuous sedimentation, although hiatuses of short duration as compared to the duration of the cycles may be present (Clement and Kent, this volume).

All these sedimentary characteristics lead us to the conclusion that the Feni and Gardar drift sediments are essentially pelagic in nature. We found no clear evidence of the "contourite" facies recognized elsewhere by Heezen and Hollister (1971), Stow and Holbrook (1984), or Gonthier et al. (1984). Our results provide little evidence of current control of the sediment deposition on the wave fields, despite the known competency of the present-day current regime and the presence of the wave fields themselves. More detailed analyses of grain size and composition, linked to an isotopic analysis of glacial-interglacial fluctuations, might allow identification of separate dissolution, productivity, and current-related effects.

\section{CHANGES IN DRIFT SEDIMENTATION THROUGH TIME}

Evidence of relatively recent changes in drift or wave field sedimentation has resulted from our examination of accumulation rate changes at Site 611 .

Compared to the average rate of Neogene and late Quaternary pelagic sedimentation in the North Atlantic (2-40 m/m.y.; Davies et al., 1977), rates of sedimentation on Feni and Gardar drifts were relatively high (between 50 and $60 \mathrm{~m} / \mathrm{m}$.y.). The sedimentation rates at Sites 610 and 611 fluctuated significantly through time (Figs. 18 and 21) and reach $98 \mathrm{~m} / \mathrm{m}$.y. in the Quaternary on the Gardar Drift.

Ruddiman and Bowles (1976) calculated a late Pleistocene regional mean sedimentation rate of 30 to $40 \mathrm{~m} /$ m.y. from a suite of piston cores in the Northeast Atlantic. Over this period, Sites 610 and 611 have moderate excesses of sediment $(20-30 \%)$ over the regional mean, 


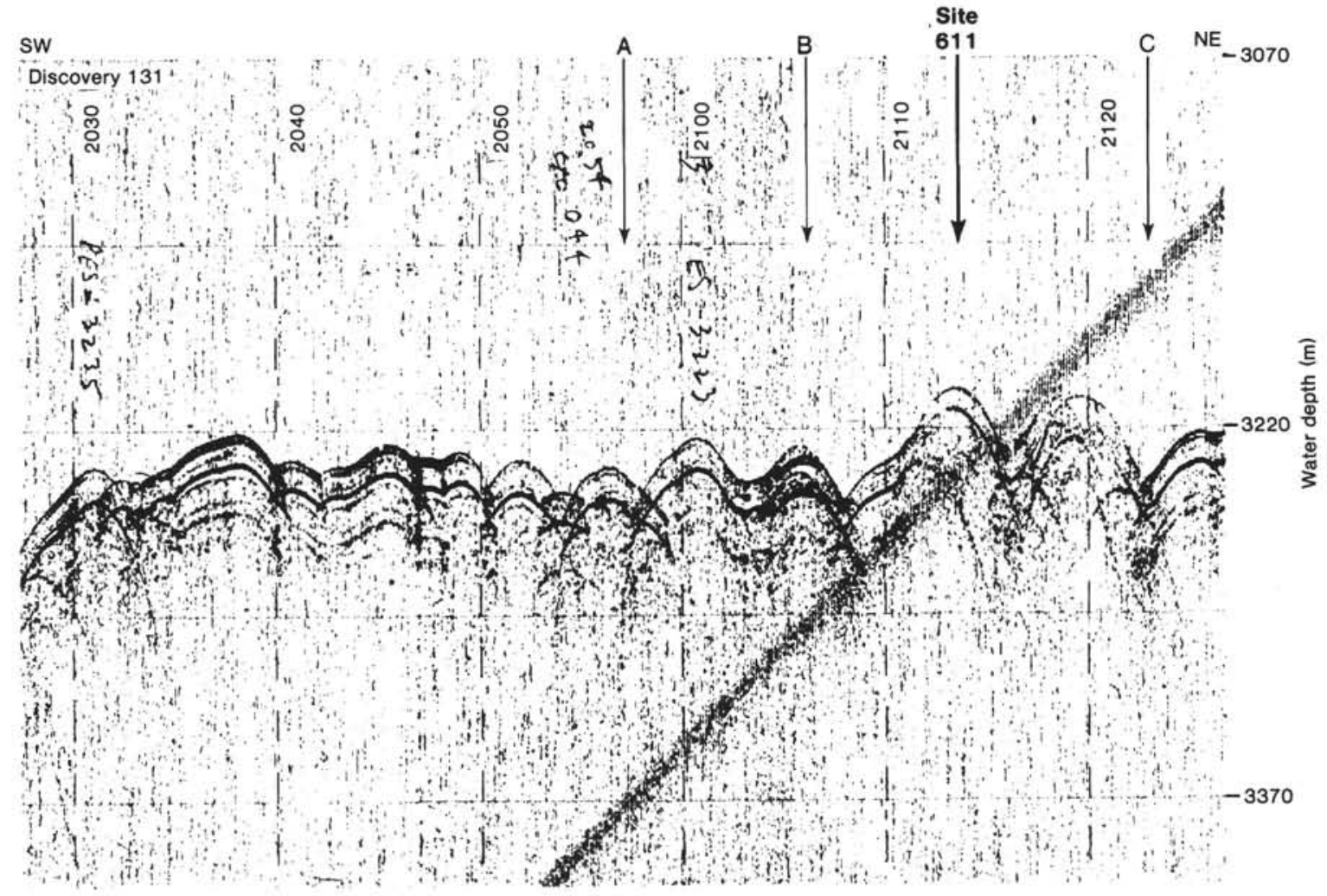

Figure 16. 3.5-kHz sounder profiles taken around DSDP Site 611. A, B, and C represent turns in the Discovery track; see Figure 15.
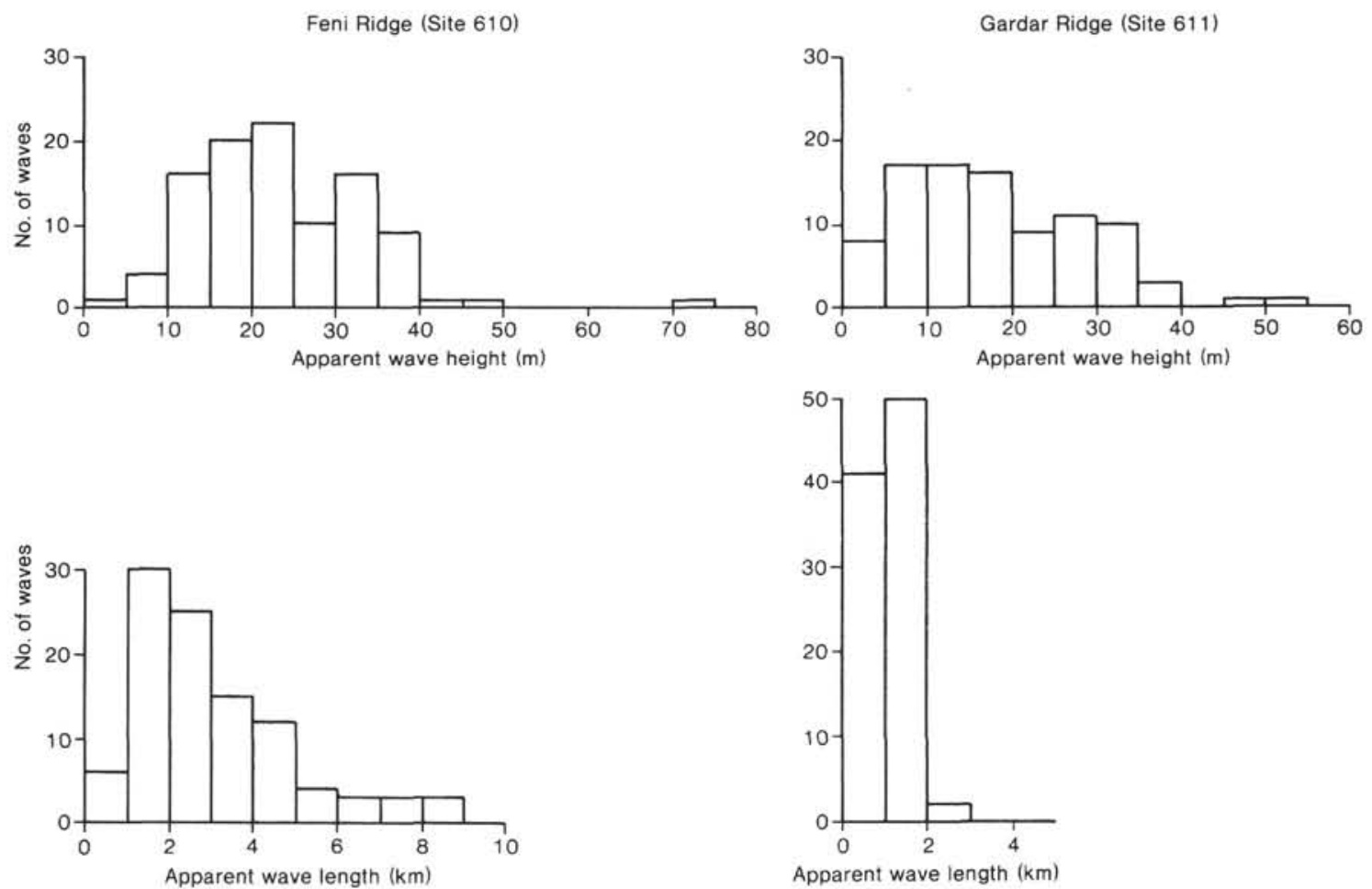

Figure 17. Histograms of apparent wave height and wavelength frequencies at DSDP Sites 610 and 611. 


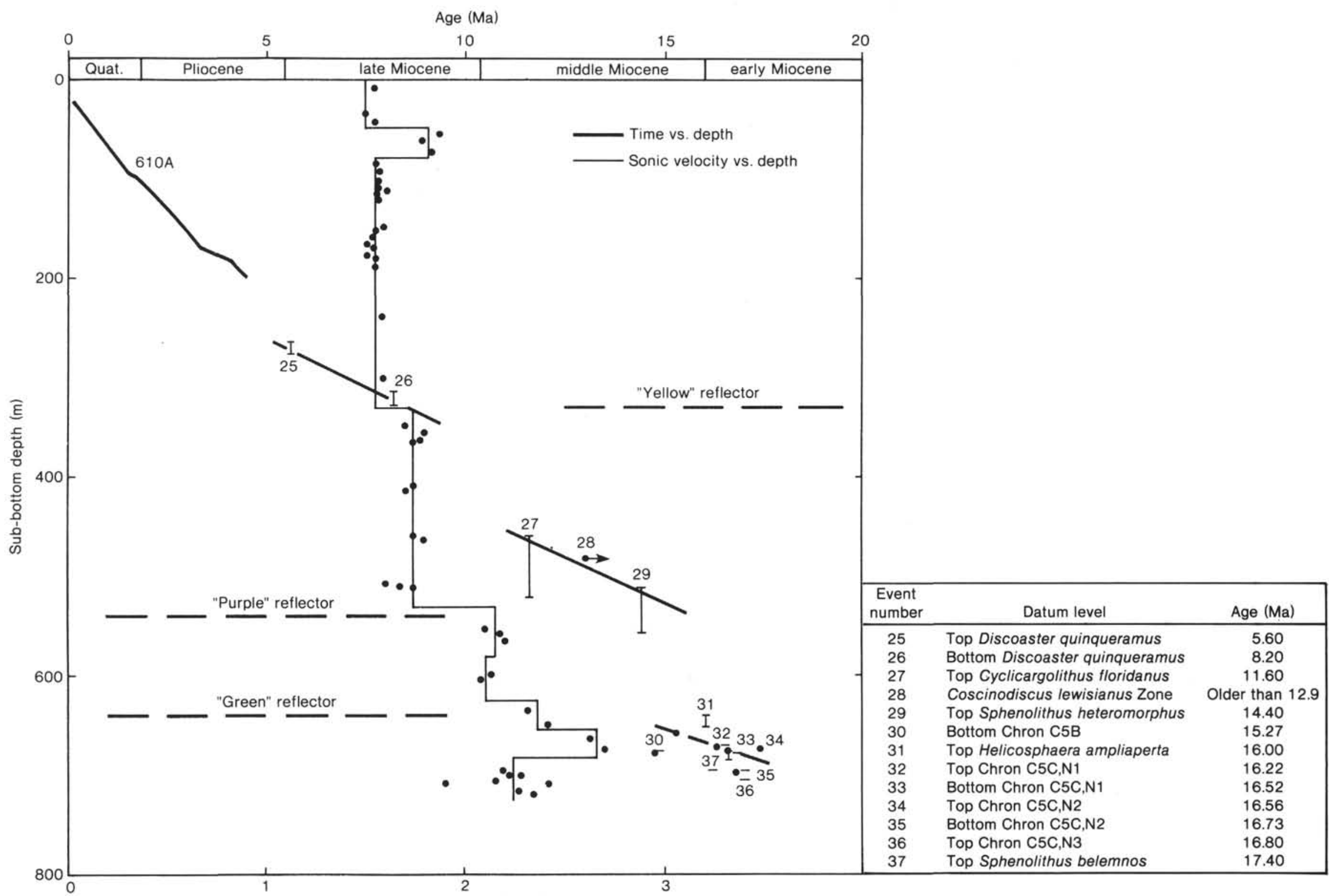

Sonic velocity $(\mathrm{km} / \mathrm{s})$

Figure 18. DSDP Site 610 age versus depth and sonic velocity versus depth plots combined for comparison with the levels of the "yellow," "purple," and "green" reflectors (Masson and Kidd, this volume). The upper $200 \mathrm{~m}$ of the sedimentation rate curve is from the high-resolution stratigraphy for Hole 610A (Baldauf et al., this volume); ages of epoch boundaries are also after Baldauf et al. (this volume). All data below $200 \mathrm{~m}$ are numbered and referable to those plotted in the Site 610 report. The various possible interpretations linking datums 25 through 37 are shown to the right. 
Table 3. Suggested correlations of seismic reflectors recognized within the Feni Drift sequence.

\begin{tabular}{|c|c|c|c|}
\hline Age & $\begin{array}{c}\text { Masson } \\
\text { and Kidd } \\
\text { (this volume) }\end{array}$ & $\begin{array}{c}\text { Dingle } \\
\text { et al., } \\
1982\end{array}$ & $\begin{array}{c}\text { Miller and } \\
\text { Tucholke } \\
1983\end{array}$ \\
\hline late late Miocene & "Yellow" & & "R1" \\
\hline mid-middle Miocene & "Purple" & & \\
\hline latest early Miocene & "Green" & "Challenger" & "R2" \\
\hline late Eocene-early Oligocene & "Brown" & "Charcot" & "R4" \\
\hline
\end{tabular}

which argues for lateral transport. Apparently the modern sedimentation mechanism has to be able to drape laterally introduced sediment equally across the topography (W. F. Ruddiman, personal communication, 1985).

Drilling at the Gardar Drift enabled us to test the idea that the migration of sediment waves during earlier periods is reflected in systematic differences in sedimentation rate between the crest and an adjacent trough of the wave. Excellent control on the sedimentation rates was provided by a combination of high-resolution magnetostratigraphy and biostratigraphy using nannofossils, foraminifers, and diatoms (Baldauf et al., this volume).

The curves show that, during the Pleistocene, sedimentation rates were approximately equal at the crest $(611,611 \mathrm{D})$ and trough $(611 \mathrm{C})$ of the wave (Fig. 21A). During the late Pliocene, however, both locations experienced higher sedimentation rates, and the rate of accretion at the crest was significantly higher than in the trough. The two curves cross at approximately $3.5 \mathrm{Ma}$. Unfortunately, the crest holes were terminated at this level, $230 \mathrm{~m}$ sub-bottom, so that early Pliocene and Miocene rates cannot be compared. The rate at the trough site increases very slightly into the late Miocene.

Figure 21B shows an interpretation of these curves based on sediment wave migration. The depths below sea level of the two locations are plotted for several time planes. We fitted the morphology of the drilled sediment wave to the points for each time plane. The results suggest that sediment waves migrated during the late Pliocene. We can infer that a major change in conditions at the Pliocene/Pleistocene boundary stopped migration and led to deposition of a uniform drape of sediment during the Pleistocene. We cannot determine the mechanisms responsible for this change in sedimentation. The switch could have been brought about by a change in paleocirculation, or by the interference of two sets of sediment waves. In support of our migration model, we can say: (1) the migration in the Pliocene involved an increase in sedimentation rate at the present-day crest site, without a corresponding decrease at the trough site; (2) the scale of migration with respect to wavelength and amplitude of the waves is comparable to that of sediment waves where apparent migration can be identified on seismic profiles; and (3) the interpretation of Pleistocene "drape" is supported by seismic profiles of the sediment waves at Gardar, where no migration directions can be determined.

\section{VARIABILITY IN THE MODERN CURRENT REGIME}

Dickson and Kidd (this volume) present results from year-long current meter records over the U.K. Ministry of Agriculture, Food and Fisheries (MAFF) Rockall Bank Array, a line of current meter stations measuring at around $1000-\mathrm{m}$ intervals through the water column and spaced from Rockall Plateau eastwards into the central Rockall Trough. Peak current speeds as recorded by the deepest current meters at $45 \mathrm{~m}$ above bottom (Fig. 22) are in the range of 27 to $39 \mathrm{~cm} / \mathrm{s}$, well above current speeds that would allow deposition of silt- and clay-sized sediment particles (McCave, 1984). More important in assessing the deposition of the recovered sequences are Dickson and Kidd's calculations of the percentage of the year's record that bottom currents were in excess of $10 \mathrm{~cm} / \mathrm{s}$, $20 \mathrm{~cm} / \mathrm{s}$, and $30 \mathrm{~cm} / \mathrm{s}$. For the station most representative of Site 610 (Station 82-07/16), these time percentages were $35 \%, 4 \%$, and $<1 \%$, respectively. It is likely that current speeds at the sediment/water interface exceed those $45 \mathrm{~m}$ above in the water column, so representative percentages there may be somewhat greater.

Although measured near-bottom currents are generally contour parallel, Dickson and Kidd showed that there is considerable variability in both current strength and directional stability. The most constant contour-following currents were recorded on the steeper slopes downflank from Site 610 at over $3000 \mathrm{~m}$ water depth.

No investigation has yet been made of a possible correlation of peak modern-day overflow events into the northern Rockall Trough with peak velocities recorded on arrays such as that across the southern Feni Ridge. Modern overflow is maximal during the summer and tends to shut off during the winter west-wind maximum (H. D. Dooley, personal communication, 1984). The nearbottom current meter record displaying the most steady current directions, at $3117 \mathrm{~m}$, records its current velocity maximum in the mid-October to mid-May period, suggesting that the southern sources of bottom water are dominant at that location. At the 2453-m Station (82$07 / 16$ ), velocity maxima occur in periods of great directional instability during mid-April to mid-June and midAugust to mid-September. These data again suggest that the overflow events have little effect on the southern Feni Drift. If this inverse relationship to the westerly storms could be extended to the glacial periods, we might expect that the combination of this effect and a sea level drop during glacial periods might limit severely the influence of NSOW on Feni Drift sedimentation.

\section{DISCUSSION}

When we consider the results of the Leg 94 drilling at Sites 610 and 611 it is clear, with hindsight, that our initial premise (i.e., that an investigation of the development of the sediment wave fields would provide the key to an understanding of the overall drift development) proved unfounded: we unlocked a host of questions rather than answers. All of the information available to us 


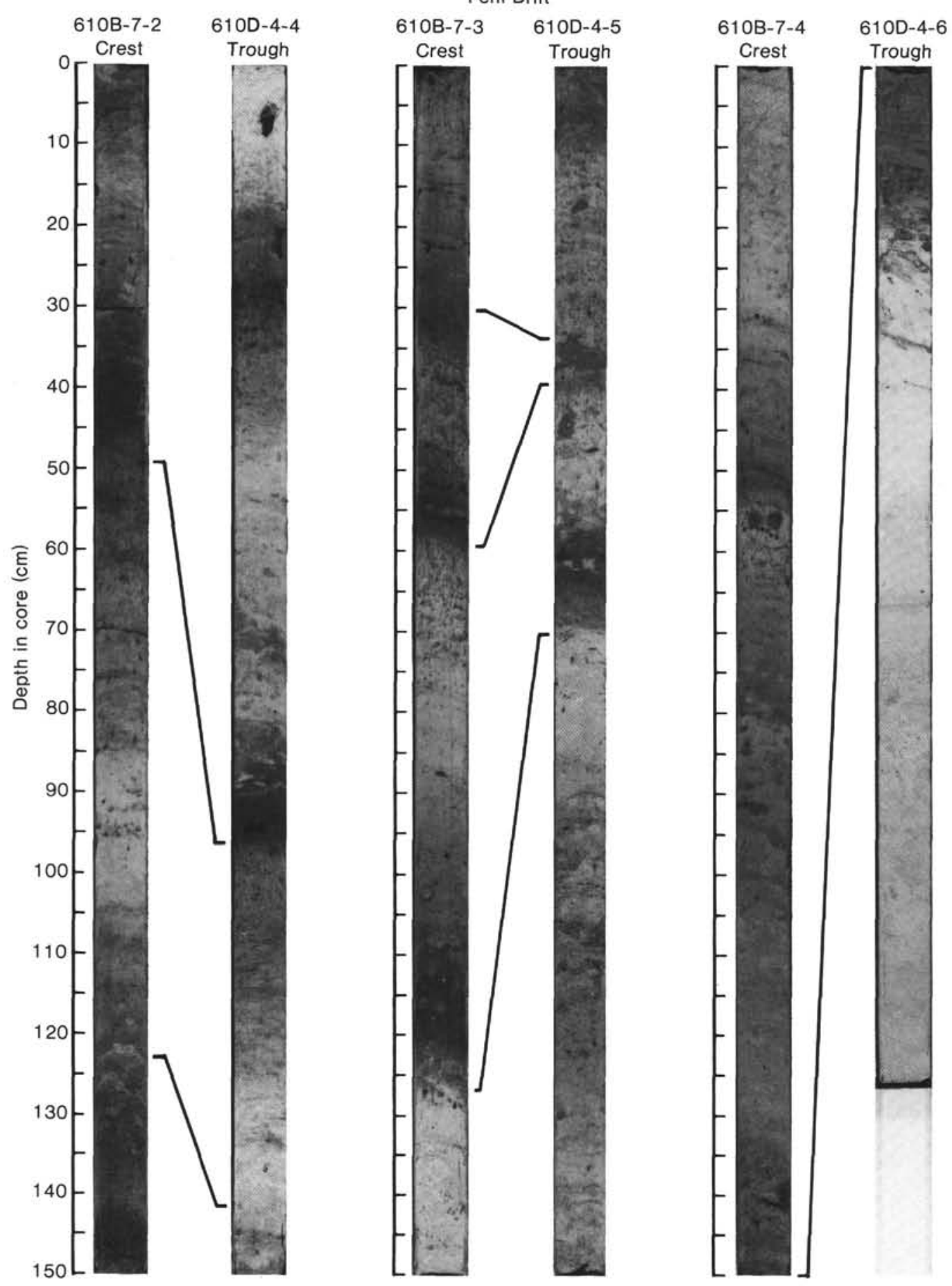

Figure 19. Photographs of HPC (hydraulic piston core) sections from sediment wave crest and trough holes at Site 610 illustrating visual correlations of glacial cycles. Most thickness differences are attributable to core sampling discrepancies (Ruddiman et al., this volume). See also volume frontispiece.

prior to drilling suggested that we might expect to measure appreciable differences in sedimentation on wave crests and in troughs; and that these changes might vary both spatially and through the cyclic changes from glacial to interglacial in the Quaternary and upper Pliocene. At both drift sites, in different locations relative to overall drift morphology, the upper Pliocene and Qua- ternary sequences are effectively a pelagic "drape" that records all the glacial cycles and lacks hiatuses or evidence of differences in relative accumulation rates. Although we recognize that some relative differences in local sedimentation rate must occur in order to maintain the morphology of the wave fields, the period of active wave migration appears to have been prior to the initia- 


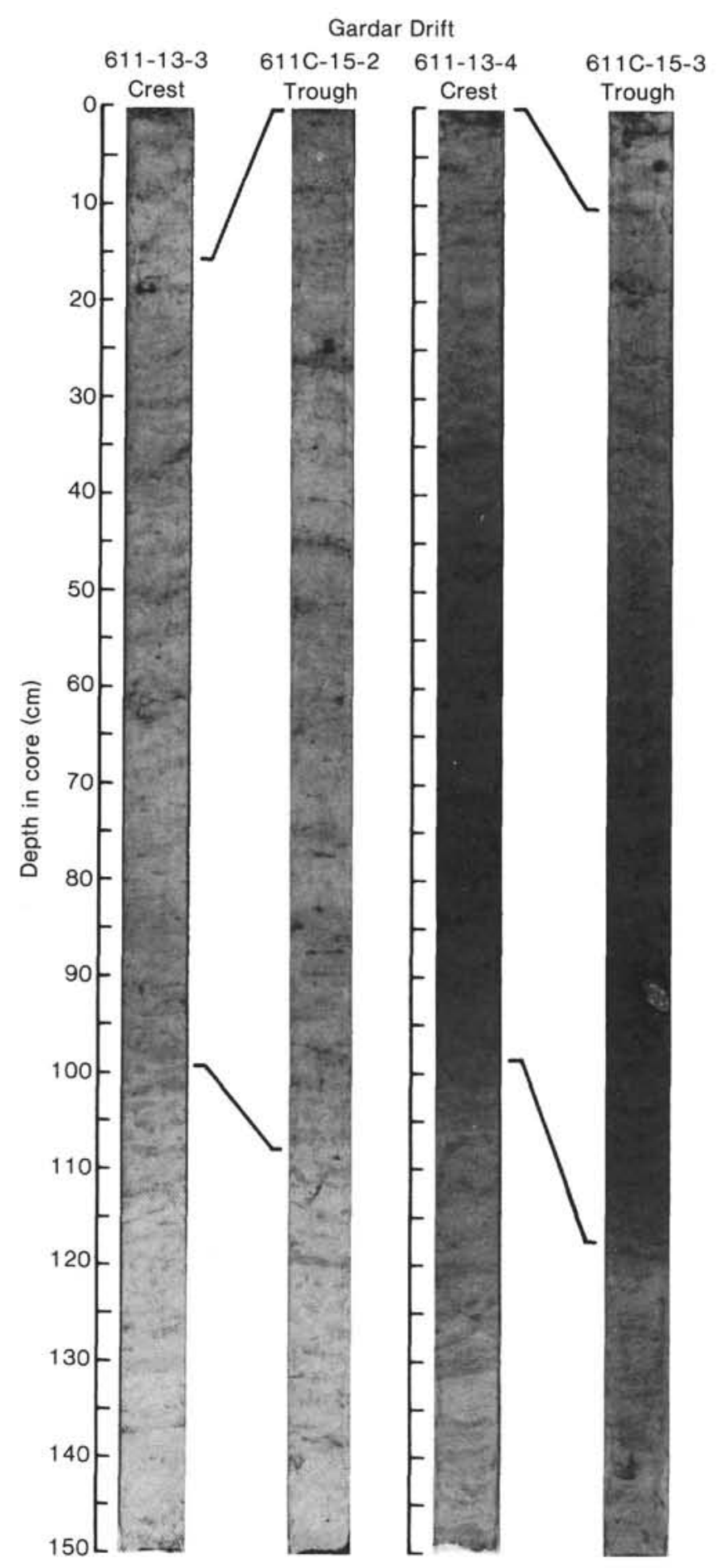

Figure 20. Photographs of HPC core sections from sediment wave crest and trough holes at Site 611. Note the more terrigenous (darker) aspect of the interglacial intervals compared to Site 610 (Fig. 19).

tion of the glacial cycles at about $2.4 \mathrm{Ma}$. For Sites 610 and 611 we have to consider three periods in the history of the sediment wave fields: (1) the period of wave formation, (2) the period of wave migration, and (3) the period of wave maintenance or "drape."

Let us consider primarily the period of active sediment wave migration. In seismic profiles, neither site shows evidence of migration, although acoustic evidence of migration is evident elsewhere, at least on Feni Drift. Neither shows lithologic evidence of either major current activity or of migration. Only at Site 611 can we show sedimentation rate evidence of Pliocene migration. Migration may also have occurred at the Feni Site 610, but our drilling was not organized to allow us to obtain such evidence there.

We reviewed data on sediment waves in other environments, in a search for process parameters that might be relevant to the drift waves. Normark et al. (1980) recognized that three different origins have been proposed for sediment waves in the oceanic environment: (1) sediment waves resulting from turbidity current flow-most commonly found on levees of submarine fans and deep marine channels (Nowroozi et al., 1968; Tucholke, 1975; Hess and Normark, 1976; Damuth and Hayes, 1977); (2) sediment waves developed on continental rises and on drifts (see Table 2); and (3) sediment waves caused by downslope slumping, usually on continental margins or insular slopes (Ballard, 1966; Kenyon et al., 1978).

Our review added further examples to the second category. Without exception, acoustic profiles for all three categories show sediment wave migration in an upslope direction. In addition to those in the second category that we list for the North Atlantic (Table 2), Normark et al. (1980) cited waves on drifts described by Bouma and Hollister (1973), Ewing et al. (1968), and Kolla et al. (1976) from the Indian Ocean; and Ewing et al. (1971) and Jacobi et al. (1975) from farther south in the Atlantic Ocean. Almost all have an upcurrent sense of migration. But interestingly, both Ewing et al. papers (1968; 1971) show acoustic evidence of downcurrent wave migration. The only other case of downcurrent migration of sediment waves is that of Feni Drift (Roberts and Kidd, 1979).

A number of studies have reported two types of sediment wave occurring in the same area, for example, waves supposed to result from both turbidity currents and slumping occur in the Colombian Basin (Bouma and Treadwell, 1975) and waves with both turbidity and bottom current origins in the western equatorial Atlantic (Damuth, 1975).

\section{Turbidity Currents}

Investigations of the sediment waves related to turbidity currents provide us with some parameters that might affect wave development, even though our drilling results show it is not likely that turbidity current processes have been active on the Feni and Gardar drifts. Normark et al. (1980) discussed sediment waves on a Monterey Fan channel levee and attempted to infer flow characteristics from the wave dimensions by assuming a reasonable range of flow velocities for dilute (muddy) turbidity currents. Their analysis assumed the waves to be depositional bed forms of the antidune type and they modified an equation of Allen (1970) for subaerial flows, to arrive at the relationship

$$
L=\frac{2 \pi}{\mathrm{g}} \cdot \frac{\mu^{2}}{1.6 C}
$$


A

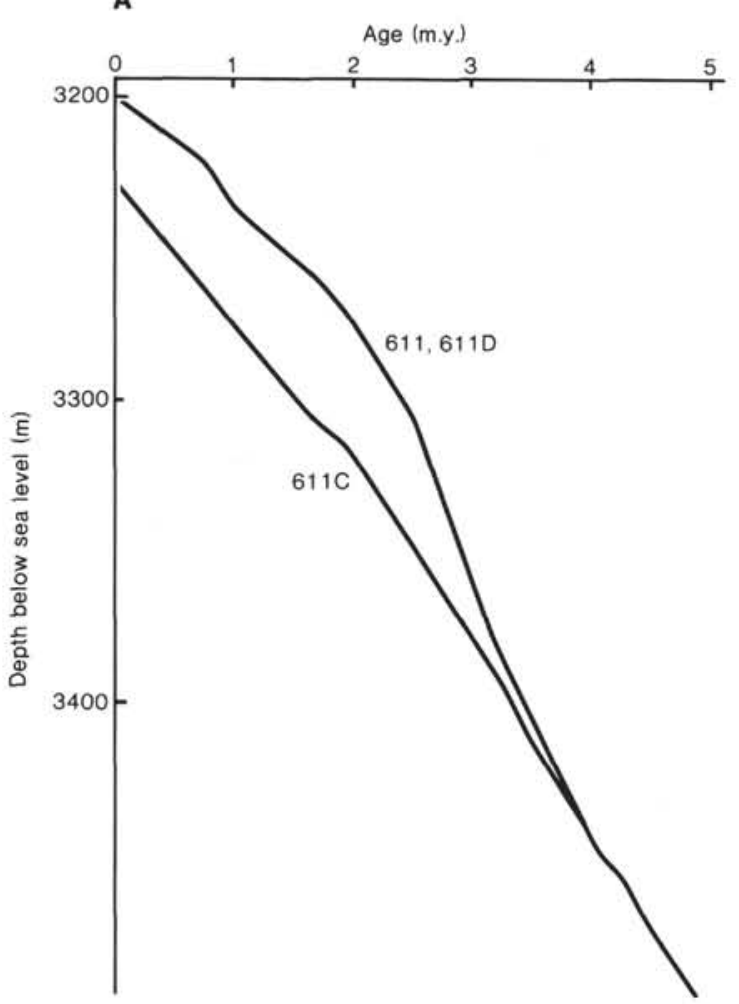

B

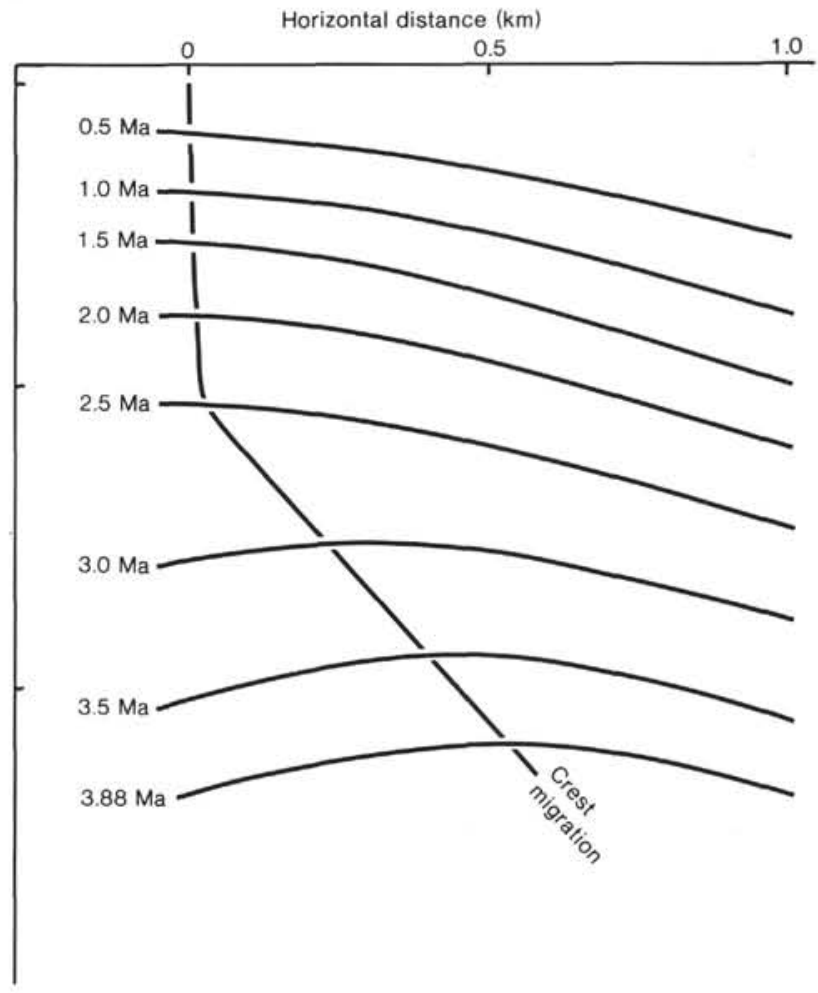

Figure 21. A. Sedimentation rate curves for DSDP Site 611 . The trough hole, $611 \mathrm{C}$, is offset on the vertical axis by $32 \mathrm{~m}$, equivalent to the amplitude of the sediment wave. B. Interpretation of the sedimentation rate curves, indicating possible Pliocene migration and Quaternary "drape" or "wave maintenance."

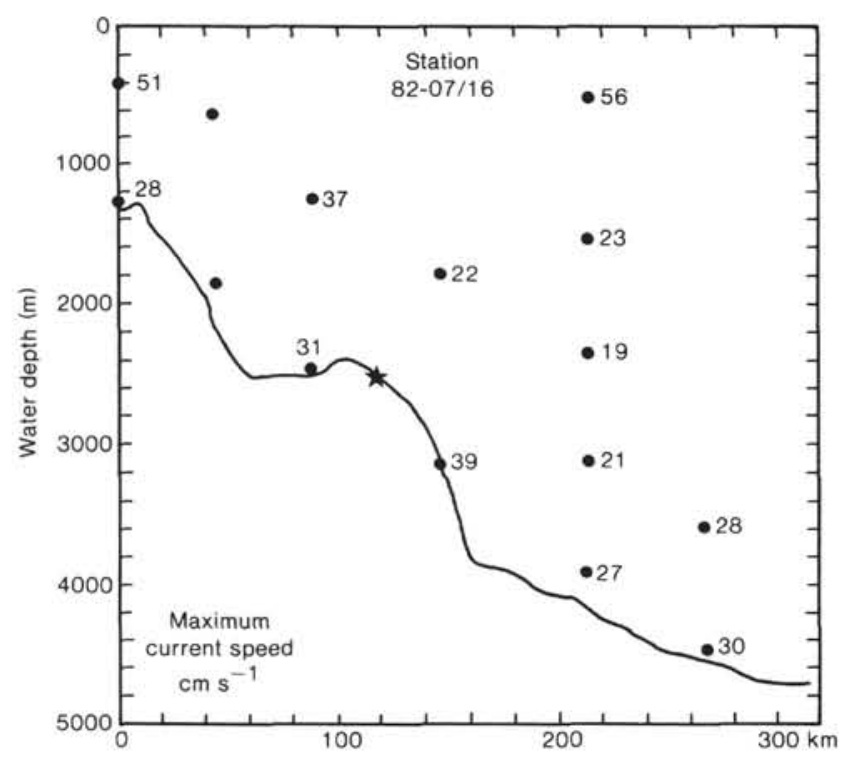

Figure 22. Bathymetric section of Feni Ridge and the MAFF (Ministry of Agriculture, Food and Fisheries) Rockall Current Meter Array with maximum current speeds $(\mathrm{cm} / \mathrm{s})$ measured at each location in the year-long deployment, from Dickson and Kidd (this volume). Star locates approximate relative location of Site 610 .

where $L$ is the wavelength of the sediment wave, $\mu$ is the flow velocity, $C$ is a (dimensionless) sediment concentration, and $\mathrm{g}$ is a gravity constant. Thus for flow velocities in the order of $20 \mathrm{~cm} / \mathrm{s}$ and wavelengths of 0.5 to $5 \mathrm{~km}$, concentrations in the range $3.2 \times 10^{-6}$ to $3.2 \times 10^{-5}$ $(8-80 \mathrm{mg} / \mathrm{l})$ are obtained. These concentrations are clearly higher than ambient deep-sea suspended sediment concentrations, because the mechanism requires a significant excess density.

Although the relationship just described is instructive in its recognition of the importance of sediment concentration in any mechanism we invoke here, we have no evidence to support the hypothesis that sediment waves on the Feni or Gardar drifts might be related to turbidity currents. The cores show no turbidite structures (Hill, this volume; Sites 610 and 611 reports, this volume), and the sedimentation rates are very low compared to continental margin rates. For the Feni Ridge, Lonsdale and Hollister (1979) had previously suggested that turbidity currents supplying the Barra and Donegal fans in the eastern Rockall Trough could have entrained sediment in the eastern slope current; this sediment could subsequently have been transferred to the drift. Depth differences between this slope water mass, the fans, and the crestal regions of the drift seem to preclude this notion as it seems more likely that entrainment and westward transfer of dilute slope nepheloid layers has occurred (Dickson and McCave, 1982). For the Gardar Drift, turbidity currents could be contributing Icelandic volcanogenic material to lower flank settings by overbank deposition from the Maury Channel (Cherkis et al., 1973; McCave et al., 1980). As with the Feni drift, the drilling results show turbidites to be a very minor component of 
the overall sediment sequence. Certainly there appears no source on either drift for entraining high concentrations of either terrigenous or pelagic sediment.

\section{Slumping}

There are insufficient sampling and survey data to comment on the likelihood of slumping affecting the Gardar Drift, but there is ample evidence that slumping has occurred on Feni Drift (Roberts, 1972; Flood, 1978). These studies, however, investigated discrete slumped masses that disrupt the morphology of the sediment wave fields (Roberts and Kidd, 1979) and are dated as late Quaternary, occurring during glacial low sea-level stands (Faugères et al., 1981). We looked carefully for evidence of creep or slumping in the cores and found no such structures at Site 610 (Hill, this volume). The occurrence of distorted foraminifers deeper in the section led us to consider tectonic warping as a contributor to the overall shape of the drift (see Site 610 report, this volume). Slumping, creep, and tectonic warping might be considered possible mechanisms for initiation of the wave shapes but we do not invoke them as a primary cause of their buildup and migration.

\section{Bottom Currents}

We are essentially left with the theory that primary development of the sediment waves is indeed related to bottom current processes. In the absence of site-specific data on modern-day sediment transport, we aim here to identify possible mechanisms and important controlling factors and thus to point the way to further research.

McCave (1984) reviewed the various factors that control transport, aggregation, and deposition of fine-grained sediments; we attempt to apply his principles to the drift sediments. Although the current meter data on the modern current regime, as described in Dickson and Kidd (this volume), come from no closer than $45 \mathrm{~m}$ above bottom, we assume that the records give an approximation of near-bottom currents. Current velocity $(\mu)$ can be transformed to bed shear velocity $\left(\mu^{*}\right)$ using the equation:

$$
\mu^{*}=\mu \sqrt{\mathrm{C}_{\mathrm{D}}}
$$

where $C_{D}$ is the drag coefficient (Stow and Bowen, 1980), assumed to be of the order of 0.003 (McCave and Swift, 1976). The exceedance velocities (as defined by Dickson and Kidd, this volume) for $\mu^{*}$ values corresponding to 10,20 , and $30 \mathrm{~cm} / \mathrm{s}$ are indicated on Figure 23, a plot from McCave (1984) illustrating proposed transport and deposition fields for fine-grained sediments. Dickson and Kidd's current meter measurements (this volume) suggest that particles with sizes equivalent to the two modes for "coccoliths" and "foraminifers" (as identified by Hill, this volume), would remain in transport for up to $30 \%$ of the time. The predominant period of variability for currents in this region appears to be on the order of 0.5 day (tidal) to several days (Dickson et al., 1985), whereas the residence times of grains of that size are on the order of days to months (McCave and Swift, 1976).
Most particles would therefore not reach the bottom before undergoing further transport. Although this effect is probably reduced by flocculation in the finer modes (as aggregated particles exhibit higher settling velocities), the predicted long residence times in suspension may explain the apparent maintenance rather than migration of the sediment waves.

Were any sediment parameters different during the early Pliocene time of wave migration? The principles outlined by McCave (1984) probably hold true for carbonate oozes, although the mechanisms of aggregation may vary because of the relatively uncohesive properties of ooze particles. The geotechnical behavior of deposited ooze is more like that of a quartz silt than that of a cohesive clay (Nacci et al., 1973). As with terrigenous sediment, deposition of oozes can be described by the equation:

$$
R_{D}=C_{b} W_{s}\left(1-\tau_{o} / \tau_{e}\right) p^{\prime}
$$

where $R_{D}$ is rate of deposition, $C_{b}$ is particle mass concentration just outside the viscous sublayer, $W_{s}$ is settling velocity, $\tau_{o}$ is bed shear stress, $\tau_{e}$ is the limiting shear stress above which no deposition occurs (McCave and Swift, 1976), and $p^{\prime}$ is a probability factor that includes poorly understood processes such as organic resuspension, smoothness, and abyssal storms (Hollister and McCave, 1984).

The greatest differences in accumulation rates are observed in the transition from Pliocene to Pleistocene sediments; from active wave migration to "drape" or "maintenance." A significant change in oceanographic conditions at the end of the Pliocene led to (1) an overall decrease in sedimentation rates, and (2) a decrease in differential rates of deposition between crests and troughs of waves. The fact that both overall and differential rates have changed implies a change in both $C_{b}$ and $\tau_{o}$.

There is no evidence for a higher pelagic sediment rate of supply in the Pliocene Atlantic Ocean. In fact, average accumulation rates suggest a higher overall carbonate supply in the Pleistocene (Ruddiman and Bowles, 1976; Davies and Worsley, 1981). A higher supply to the drift areas must therefore have been related to more local factors and points towards a change in circulation patterns, which made the drift areas preferential sites of deposition in the Pliocene.

Such a change in oceanic circulation could also account for the change in differential sedimentation rates between crest and trough by altering the near-bottom current regime. A less extremely variable climate and lack of winter storm activity during the Pliocene should have allowed a more vigorous role for Norwegian Sea Overflow Water. We therefore suggest that the main cause of the wave migration period was vigorous NSOW bottom current activity, which became restricted from the late Pliocene onwards.

\section{Internal Waves}

Murray (this volume) has tentatively suggested (from benthic foraminiferal evidence) that the influence of Ant- 


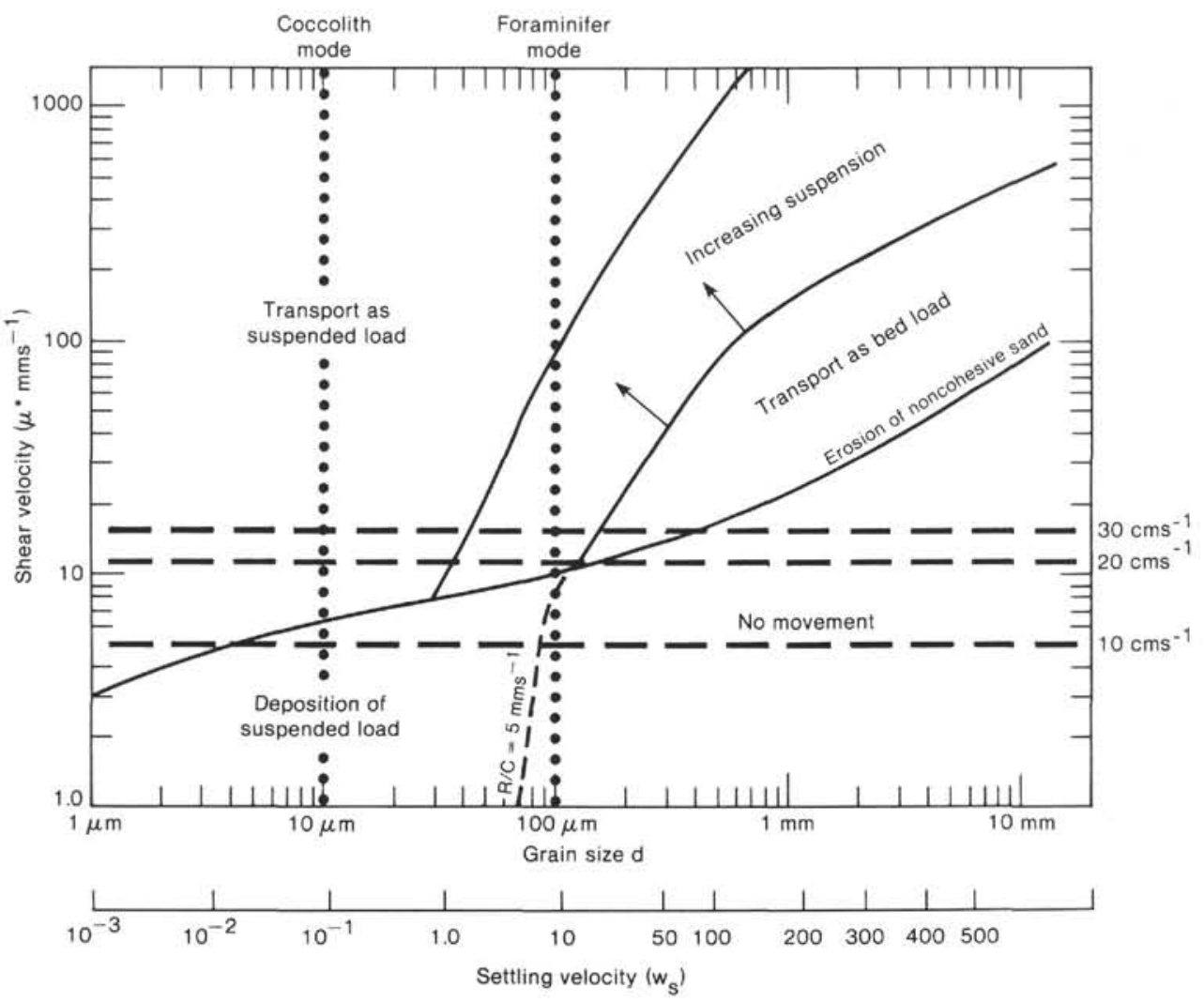

Figure 23. Proposed transport and deposition diagram for fine suspended sediment from McCave (1984) with erosion and transport fields for coarser materials. Plotted on this are the exceedance velocities used by Dickson and Kidd (this volume) and grain size modes for Feni Ridge sediments measured by Hill (this volume). See text for discussion.

arctic Bottom Water (AABW) was greater during the Pliocene, at least in the Rockall Trough area. A greater influence of both NSOW and AABW may have led to a distinctly stratified near-bottom water structure, and this brings up another possible mechanism. Density interfaces are often associated with internal waves that may have periods up to several days and wavelengths on the order of kilometers (Defant, 1961). Some workers have proposed internal waves as important sedimentation modifiers on continental slopes (Ewing, 1973). On the Nova Scotian continental slope, for example, internal waves are generated by the impingement of Gulf Stream eddies on the slope and cause increased current velocities of up to $10 \mathrm{~cm} / \mathrm{s}$ (Louis et al., 1982). The effects of these increased velocities can be observed in bottom sediment size distributions (Hill and Bowen, 1983), indicating that the waves "feel" the bottom. As noted previously, Dickson and Kidd (this volume) suggest that impingement of a present-day water mass interface causes the complex interplay of sediment waves near Site 610 . The presence of a bottom feature on the order of 30 to $50 \mathrm{~m}$ high would certainly set up an instability in near-bottom flow, which could propagate as an internal wave if the layer of AABW was relatively thin (on the order of a few hundred meters). The wave could be described by:

$$
C^{2}=\frac{\mathrm{g} \lambda}{2 \pi} \cdot \frac{\left(p-p^{\prime}\right)}{\left(p+p^{\prime}\right)}
$$

(Defant, 1961) where $C$ is the velocity of propagation of the internal wave, $g$ is the gravity constant, $\lambda$ is the wavelength, $p$ is the density of the lower layer, and $p^{\prime}$ the density of the upper layer. Assuming $C$ to be on the order of 1 to $10 \mathrm{~cm} / \mathrm{s}$ (cf. Louis et al., 1982) and $p-p^{\prime}$ to be on the order of $10^{-4}$ (based on the present-day properties of AABW and NSOW), the internal wavelength would be on the order of tens of meters to kilometers, corresponding well to the observed wavelengths of the sediment waves.

We emphasize that this simplistic approach is used only to present a further idea that may be important at least for the origin of sediment waves: the problem of internal waves impinging on a rough bottom topography is very complex. However, the relationship between sediment waves and a stratified near-bottom water column is one that in our opinion deserves further attention.

\section{CONCLUSIONS}

All our drilling results suggest that modern sedimentation at Site 610 on Feni Drift and Site 611 on Gardar drift is dominantly pelagic, and current (even at up to $39 \mathrm{~cm} / \mathrm{s}$ on Feni Drift) serve only to maintain the morphology of now-relict sediment wave fields. However, we do not have evidence to dispute the possibility that elsewhere on both drifts locations exist where waves are actively migrating in the modern current regime. The Quaternary and upper Pliocene sequences drilled indicated 
little or no differential crest-to-trough sedimentation differences between glacial and interglacial periods.

We present sedimentation rate data from Site 611 in support of a hypothesis that sediment waves were actively migrating on the drifts during the preglacial Pliocene. This we attribute to the major influence of vigorous Norwegian Sea Overflow Water in preglacial time; the influx diminished and became intermittent in glacial and modern times.

Acoustic evidence of the sediment waves is present on signal-channel air-gun records only in the upper 0.1 to $0.2 \mathrm{~s}$, which corresponds in age to the early Pliocene (see Sites 610 and 611 reports, this volume). This is clearly an acoustic effect, however, and we have no reason to suppose that sediment waves did not characterize the drifts in earlier times.

Probably the earliest influence of NSOW coincided with the formation of the first sediment waves, but the variability in trend, amplitude, and wavelength that we discovered in these wave fields suggests that wave fields form and are modified continually through time. We have considered two possible mechanisms to form the initial wave surface: slumping and internal waves. A third factor, that of a variable basement relief, is perhaps more relevant to Gardar Drift.

Initiation of the drifts themselves was addressed by reinterpretation of seismic coverage around Site 610 in Rockall Trough. We concur with other authors that the bases of the drifts are of Eocene-Oligocene age and that buildup of sediments began with the first influence of Norwegian Sea Overflow Water on the North Atlantic basins. We drilled through two mid-drift reflectors, one of early Miocene age that represents a major oceanographic change in Rockall Trough but apparently no hiatus, and a second of late Miocene age, which may be related to the Mediterranean isolation from the Atlantic in the Messinian. Studies of both the modern circulation of the Northeast Atlantic and the history of sedimentation of the two drifts as established by the Leg 94 drilling suggest that the influence of Norwegian Sea Overflow Water during the Pleistocene has been overemphasized in previous studies.

\section{ACKNOWLEDGMENTS}

In order to develop a synthesis chapter of this type, particularly in the event of our surprising findings on DSDP Leg 94, we have clearly drawn extensively upon the work of our shipboard and shore-based colleagues, much of it reported in this volume. The conclusions and speculation that we present, however, are entirely our own responsibility. We are thankful for useful scientific critique and suggestions on improving the manuscript from Bill Ruddiman, Ellen Thomas, Philip Weaver, Doug Masson, Jack Baldauf, Larry Meyer, Tony Bowen, and Audrey Meyer.

The shipboard scientists, technicians, and crews of the Discovery and Glomar Challenger are gratefully acknowledged for their considerable help in obtaining the data reported here.

Most of Robert Kidd's research was carried out at IOS Wormley; the manuscript, however, was written (and "agonized" over) at ODP/ TAMU, College Station. The article bears ODP designation: ODP/P85/013. Part of Philip Hill's postcruise work was carried out at Edinburgh University under a grant from the Nuffield Foundation.

Colin Jacobs, Ross Jackson, Peter Hunter, and Karen Benson prepared the figures. Anne Graham typed the manuscript.

\section{REFERENCES}

Allen, J. R. L., 1970. Physical Processes of Sedimentation: London (Unwin University Books).

Ballard, J. A., 1966. Structure of the lower continental rise hills of the western North Atlantic. Geophysics, 31:506-523.

Belderson, R. H., Kenyon, N. H., Stride, A. H., and Stubbs, A. R., 1972. Sonographs of the Seafloor: A Picture Atlas: Amsterdam (Elsevier Publ. Co.).

Bouma, A. H., and Hollister, C. D., 1973. Deep ocean basin sedimentation. In Middleton, G. V., and Bouma, A. H. (Eds.), Turbidites and Deep Water Sedimentation, Soc. Econ. Paleontol. Mineral. Short Course, Anaheim, pp. 79-118.

Bouma, A. H., and Treadwell, T. K., 1975. Deep sea dune-like features. Mar. Geol., 19:M53-M59.

Cherkis, N. Z., Flemming, H. S., and Feden, R. H., 1973. Morphology and structure of Maury Channel, Northeast Atlantic Ocean. Geol. Soc. Am. Bull., 84:1601-1606.

Crease, J., 1965. The flow of Norwegian Sea water through the Faeroe Bank Channel. Deep Sea Res., 12:143-150.

Damuth, J. E., 1975. Echo character of the western equatorial Atlantic floor and its relationship to the dispersal and distribution of terrigenous sediments. Mar. Geol., 18:17-45.

Damuth, J. E., and Hayes, D. E., 1977. Echo character of the east Brazilian continental margin and its relationship to sedimentary processes. Mar. Geol., 24:73-95.

Davies, T. A., Hay, W. W., Southam, J. R., and Worsley, T. R., 1977. Estimates of Cenozoic oceanic sedimentation rates. Science, 197: 53-55.

Davies, T. A., and Laughton, A. S., 1972. Sedimentary processes in the North Atlantic. In Laughton, A. S., Berggren, W. A., et al., Init. Repts. DSDP, 12: Washington (U.S. Govt. Printing Office), 905-934.

Davies, T. A., and Worsley, T. R., 1981. Paleoenvironmental implications of oceanic carbonate sedimentation rates. In Warme, J. E., Douglas, R. G., and Winterer, E. L. (Eds.), The Deep Sea Drilling Project: A Decade of Progress, Soc. Econ. Paleontol. Mineral. Spec. Publ., 32:169-179.

Defant, A., 1961. Physical Oceanography (Vol. 2): Oxford (Pergamon Press).

Dickson, R. R., Go:ld, W. J., Muller, T. J., and Maillard, C., 1985. Estimates of the mean circulation in the deep $(>2000 \mathrm{~m})$ layer of the eastern North Atlantic. Prog. Oceanog., 14:103-127.

Dickson, R. R., and McCave, I. N., 1982. Properties of nepheloid layers on the upper slope west of Porcupine Bank. Int. Council Explor. Sea, CM 1982/Ci2, Hydrography Committee.

Dingle, R. V., Megson, J. B., and Scrutton, R. A., 1982. Acoustic stratigraphy of the sedimentary succession west of Porcupine Bank, NE Atlantic Ocean: a preliminary account. Mar. Geol., 47:17-35.

Egloff, J., and Johnson, G. L., 1975. Morphology and structure of the Southern Labrador Sea. Can. J. Earth sci., 12:2111-2133.

Ellett, D. J., and Roberts, D. G., 1973. The overflow of Norwegian Sea Deep Water across the Wyville-Thompson Ridge. Deep Sea Res., 20:819-835.

Embley, R. W., Hoose, P. J., Lonsdale, P., Mayer, L., and Tucholke, B. E., 1980. Furrows and mud waves on the Western Bermuda Rise. Geol. Soc. Am. Bull., 91:731-740.

Ewing, J. A., 1973. Wave-induced bottom currents on the outer shelf. Mar. Geol., 15:M31-M35.

Ewing, M., Aitken, T., and Eittreim, S., 1968. Giant ripples in the Madagascar Basin. Trans. Am. Geophys. Union, 49:218.

Ewing, M., Eittreim, S. L., Ewing, J. L., and Le Pichon, X., 1971. Sediment transport and distribution in the Argentine Basin, 3: Nepheloid layer and processes of sedimentation. In Ahrens, C. H., Runcorn, S. K., and Urey, H. C. (Eds.), Physics and Chemistry of the Earth (Vol. 8): New York (McGraw-Hill), 49-77.

Faugères, J. C., Gonthier, E., Grousset, F., and Poutiers, J., 1981. The Feni Drift: the importance and meaning of slump deposits on the eastern slope of the Rockall Bank. Mar. Geol., 40:M49-M57.

Flood, R. D., 1978. Studies of deep-sea sedimentary microtopography in the North Atlantic Ocean [Ph.D. dissert.]. MIT-WHOI Joint Program in Oceanography, Woods Hole, MA (WHOI Technical Report, WHOI-78-64). 
1983. Classification of sedimentary furrows and a model for furrow initiation and evolution. Geol. Soc. Am. Bull., 94:630651.

Flood, R. D., and Hollister, C. D., 1974. Current-controlled topography on the continental margin off the eastern United States. In Burk, C. A., and Drake, C. A. (Eds.), The Geology of Continental Margins: New York (Springer-Verlag), pp. 197-205.

Flood, R. D., Hollister, C. D., and Lonsdale, P., 1979. Disruption of the Feni sediment drift by debris flows from Rockall Bank. Mar. Geol., 32:311-334.

Fox, P., and Heezen, B., 1968. Abyssal anti-dunes. Nature, 220:470472.

Gardner, J. V., and Kidd, R. B., 1983. Sedimentary processes on the Iberian continental margin viewed by long-range sidescan sonar. Part 1, Gulf of Cadiz. Oceanol. Acta, 6:245-254.

in press. Sedimentary processes on the northwestern Iberian continental margin viewed by long-range sidescan sonar. J. Sed. Petrol.

Garner, D. M., 1972. Flow through the Charlie-Gibbs Fracture Zone, Mid-Atlantic Ridge. Can. J. Earth Sci., 9:116-121.

Gonthier, E. G., Faugères, J. C., and Stow, D. A. V., 1984. Contourite facies of the Faro Drift, Gulf of Cadiz. In Stow, D. A. V., and Piper, D. J. W. (Eds.), Fine-Grained Sediments: Deep-Water Processes and Facies, Geol. Soc. Spec. Publ. 15, London (Blackwell Scientific Publishers), pp. 275-292.

Grabovskiy, N. A., 1966. Geomorphology of the ocean floor in the Grand Newfoundland Bank area. Oceanology, 6:228-237.

Grant, A. C., 1972. The continental margin off Labrador and Eastern Newfoundland: morphology and geology. Can. J. Earth Sci., 9: 1394-1430.

Heezen, B. C., and Hollister, C. D., 1971. The Face of the Deep: New York (Oxford University Press).

Heezen, B. C., Johnson, G. L., and Hollister, C. D., 1969. The northwest Atlantic mid-ocean canyon. Can. J. Earth Sci., 6:1441-1453.

Hess, G. R., and Normark, W. R., 1976. Holocene sedimentation history of the major fan valleys of Monterey fan. Mar. Geol., 22: 233-251.

Hill, P. R., and Bowen, A. J., 1983. Modern sediment dynamics at the shelf-slope boundary off Nova Scotia. In Stanley, D. J., and Lesore, G. T. (Eds.), The Shelfbreak: Critical Interface on Continental Margins, Soc. Econ. Paleontol. Mineral. Spec. Publ., 33:265276.

Hogg, N., 1980. Effects of bottom topography on ocean currents. In Orographic Effects in Planetary Flows, GARP Publication 23, World Meteorological Organisation, Geneva, pp. 167-205.

Hollister, C. D., Ewing, J. L., et al., 1972. Init. Repts. DSDP, 11: Washington (U.S. Govt. Printing Office).

Hollister, C. D., Flood, R. D., and McCave, I. N., 1978. Plastering and decorating in the North Atlantic. Oceanus, 21:5-13.

Hollister, C. D., and McCave, I. N., 1984. Sedimentation under deepsea storms. Nature, 309:220-225.

Jacobi, R. D., Rabinowitz, P. D., and Embley, R. W., 1975. Sediment waves of the Moroccan continental rise. Mar. Geol., 19:M61-M67.

Johnson, G. L., and Schneider, E. D., 1969. Depositional ridges in the North Atlantic. Earth Planet. Sci. Lett., 6:416-422.

Johnson, G. L., Sommerhoff, G., and Egloff, J., 1975. Structure and morphology of the west Reykjanes Basin and the southeast Greenland continental margin. Mar. Geol., 18:175-196.

Johnson, G. L., and Vogt, P. R., 1971. Morphology of the Bermuda Rise. Deep-Sea Res., 18:605-617.

Johnson, G. L., Vogt, P. R., and Schneider, E. D., 1971. Morphology of the Northeastern Atlantic and Labrador Sea. Dtsch. Hydrogr. Z., 24:49-73.

Jones, E. J. W., Ewing, M., Ewing, J. L., and Eittreim, S. L., 1970. Influences of Norwegian Sea Overflow Water on sedimentation in the northern North Atlantic and Labrador Sea. J. Geophys. Res., 75:1655-1680.

Kenyon, N. H., Belderson, R. H., and Stride, A. H., 1978. Channels, canyons and slump folds on the continental slope between southwest Ireland and Spain. Oceanol. Acta, 1(3):369-380.

Kidd, R. B., Flood, R. D., Roberts, D. G., and Gardner, J. V., 1980. GLORIA survey of the Blake-Bahama Outer Ridges. Inst. Oceanog. Sci. Cruise Rept. 103

Kidd, R. B., and Hill, P. R., in press. Sedimentation on mid-ocean sediment drifts. In Summerhayes, C., and Shackleton, N. J. (Eds.),
North Atlantic Paleoceanography, J. Geol. Soc. London Spec. Publ.

Kidd, R. B., and Roberts, D. G., 1982. Long-range sidescan sonar studies of large-scale sedimentary features in the North Atlantic. Bull. Inst. Geol. Bassin d'Aquitaine, Bordeaux, 31:11-29.

Kolla, V., Moore, D. G., and Curray, J. R., 1976. Recent bottom current activity in the deep western Bay of Bengal. Mar. Geol., 21: 255-270.

Laine, E. P., and Hollister, C. D., 1981. Geological effects of the Gulf Stream system on the northern Bermuda Rise. Mar. Geol., 39:277310.

Laughton, A. S., Berggren, W. A., et al., 1972. Init. Repts. DSDP, 12: Washington (U.S. Govt. Printing Office).

Laughton, A. S., Roberts, D. G., Hunter, P. M., 1984. Reykjanes Ridge and Rockall Plateau-Bathymetry of the North Atlantic, Sheet 1. Institute of Oceanographic Sciences (Map), Wormley, United Kingdom.

Lee, A., and Ellett, D., 1965. On the contribution of overflow water from the Norwegian Sea to the hydrographic structure of the North Atlantic Ocean. Deep Sea Res., 12:129-142.

Lonsdale, P., 1982. Sediment drifts of the Northeast Atlantic and their relationship to the observed abyssal currents. Bull. Inst. Geol. Bassin d'Aquitaine, Bordeaux, 31:141-149.

Lonsdale, P., and Hollister, C. D., 1979. A near-bottom traverse of Rockall Trough: hydrographic and geologic inferences. Oceanol. Acta, 2(1):91-105.

Lonsdale, P., Hollister, C. D., and Mayer, L., 1981. Erosion and deposition in interplain channels of the Maury channel system, Northeast Atlantic. Oceanol. Acta., 4:185-201.

Louis, J. P., Petrie, B. D., and Smith, P. C., 1982. Topographic Rossby waves on the continental slope off Nova Scotia. J. Phys. Oceanog., 12:47-55.

Lowrie, A., and Heezen, B., 1967. Knoll and sediment drift near Hudson Canyon. Science, 157:1552-1553.

Luyendyk, B. P., Cann, J. R., et al., 1979. Init. Repts. DSDP, 49: Washington (U.S. Govt. Printing Office), 22.

McCave, I. N., 1984. Erosion, transport, and deposition of fine-grained marine sediments. In Stow, D. A. V., and Piper, D. J. W. (Eds.) Fine-Grained Sediments: Deep Water Processes and Facies, Geol. Soc. London Spec. Publ., 15:35-69.

McCave, I. N., Lonsdale, P. F., Hollister, C. D., and Gardner, W. D., 1980. Sediment transport over the Hatton and Gardar contourite drifts. J. Sediment. Petrol., 50:1049-1062.

McCave, I.N., and Swift, S. A., 1976. A physical model for the rate of deposition of fine-grained sediments in the deep sea. Geol. Soc. Am. Bull., 87:541-546.

McGregor, B. A., Betzer, P. R., and Krause, D. C., 1973. Sediments in the Atlantic Corner seamounts: control by topography, paleowinds, and geochemically-detected modern bottom currents. Mar. Geol., 14:179-190.

Miller, K. G., 1982. Late Paleogene (Eocene to Oligocene) palaeoceanography of the northern North Atlantic [Ph.D. dissert.]. MITWHOI Joint Program in Oceanography, Woods Hole, MA.

Miller, K., and Tucholke, B. E., 1983. Development of Cenozoic abyssal circulation south of the Greenland-Scotland Ridge. In Bott, M. H. P., Saxov, S., Talwani, M., and Thiede, J. (Eds.), Structure and Development of the Greenland-Scotland Ridge: New Methods and Concepts: New York (Plenum Press), pp. 549-589.

Nacci, V. A., Kelly, W. E., Wang, M. C., and Demars, K. R., 1973. Strength and stress-strain characteristics of cemented deep-sea sediments. In Inderbitzen, A. L. (Ed.), Deep Sea Sediments: Physical and Mechanical Properties: New York (Plenum Press), pp. 129150.

Normark, W. R., Hess, G. R., Stow, D. A. V., and Bowen, A. J., 1980. Sediment waves on the Monterey Fan levee: a preliminary physical interpretation. Mar. Geol., 37:1-18.

Nowroozi, A., Ewing, M., Nafe, J., and Fliegel, M., 1968. Deep ocean current and its correlation with the ocean tide off the coast of northern California. J. Geophys. Res., 73:1921-1932.

Pastouret, L., Auffret, A., Hoffert, M., Melguen, M., Needham, H. D., and Latouche, C., 1975. Sedimentation sur la Ride de TerreNueve. Can. J. Earth Sci., 12:1019-1035.

Richardson, P. L., 1977. On the crossover between the Gulf Stream and the Western Boundary Undercurrent. Deep-Sea Res., 24:139159. 
Roberts, D. G., 1972. Slumping on the eastern margin of the Rockall Bank, North Atlantic Ocean. Mar. Geol., 13:225-237.

1975. Marine geology of the Rockall Plateau and Trough. Philos. Trans. R. Soc. London Ser. A, 278:447-509.

Roberts, D. G., Bott, M. H. P., and Uruski, C., 1983. Structure and origin of the Wyville-Thompson Ridge. In Bott, M. H. P., Saxov, S., Talwani, M., and Thiede, J. (Eds.), Structure and Development of the Greenland-Scotland Ridge: New Methods and Concepts: New York (Plenum Press), pp. 133-158.

Roberts, D. G., Hunter, P. M., and Laughton, A. S., 1979. Continental margin around the British Isles-bathymetry of the North Atlantic, Sheet 2. Institute of Oceanographic Sciences (Map), Wormley, United Kingdom.

Roberts, D. G., and Kidd, R. B., 1979. Abyssal sediment-wave fields on Feni Ridge, Rockall Trough: long-range sonar studies. Mar. Geol., 33:175-191.

1985. Sedimentary and structural patterns on the Iberian continental margin; an alternative view of continental margin sedimentation. Mar. Petrol. Geol., 2:210-221.

Roberts, D. G., Masson, D. G., and Miles, P. R., 1981. Age and structure of the Southern Rockall Trough: new evidence. Earth Planet. Sci. Lett., 52:115-128.

Ruddiman, W. F., 1972. Sediment distribution on the Reykjanes Ridge: seismic evidence. Bull. Geol. Soc. Am., 83:2039-2062.

Ruddiman, W. F., and Bowles, F. A., 1976. Early interglacial bottom current sedimentation on the eastern Reykjanes Ridge. Mar. Geol., 21:119-120.

Schneider, E. D., and Heezen, B., 1966. Sediments of the Caicos Outer Ridge, the Bahamas. Geol. Soc. Am. Bull., 77:1381-1398.

Shor, A. N., and Poore, R. Z., 1979. Bottom currents and ice rafting in the North Atlantic; interpretation of Neogene depositional environments of Leg 49 cores. In Luyendyk, B. P., Cann, J. R., et al., Init. Repts. DSDP, 49: Washington (U.S. Govt. Printing Office), 859-872.

Sibuet, J.-C., Ryan, W. B. F., et al., 1979. Init. Repts. DSDP, 47, Pt. 2: Washington (U.S. Govt. Printing Office).

Silva, A. J., Hollister, C. D., Laine, E. P., and Beverly, B. E., 1976. Geotechnical properties of deep sea sediments: Bermuda Rise. Mar. Geotech., 1:195-232.
Stow, D. A. V., 1982. Bottom currents and contourites in the North Atlantic. Bull. Inst. Geol. Bassin d'Aquitaine, Bordeaux, 31:151166.

Stow, D. A. V., and Bowen, A. J., 1980. A physical model for the transport and sorting of fine-grained sediment by turbidity currents. Sedimentology, 27:31-46.

Stow, D. A. V., and Holbrook, J. A., 1984. North Atlantic contourites: an overview. In Stow, D. A. V., and Piper, D. J. W. (Eds.), Fine-Grained Sediments: Deep-Water Processes and Facies: London (Blackwell Scientific Publishers), Geol. Soc. London Spec. Publ., 15: 245-256.

Tucholke, B. E., 1975. Sediment distribution by the Western Boundary Undercurrent: the Greater Antilles Outer Ridge. J. Geol., 83: 177-207.

1979. Furrows and focussed echoes on the Blake Outer Ridge. Mar. Geol., 31:M13-M20.

Tucholke, B. E., and Ewing, M., 1974. Bathymetry and sediment geometry of the Greater Antilles Outer Ridge and vicinity. Bull. Geol. Soc. Am., 85:1789-1802.

Tucholke, B. E., and Laine, E. P., 1982. Neogene and Quaternary development of the lower continental rise off the current United States east coast. In Watkins, J. S., and Drake, C. L. (Eds.), Studies in Continental Margin Geology, Am. Assoc. petrol. Geol. Mem., 34:295-305.

Van Hinte, J. E., Wise, S. W., Biart, B., Covington, J., Dunn, D., Haggerty, J., Johns, M., Meyers, P., Moullade, M., Muza, J., Ogg, J., Okamura, M., Sarti, M., and von Rad, U., 1985. DSDP Site 603: first deep ( $>1000-\mathrm{m})$ penetration of the continental rise along the passive margin of eastern North America. Geology, 13:392396.

Worthington, L. V., 1976. On the North Atlantic Circulation, Johns Hopkins, Oceanographic Studies No. 6: Baltimore (Johns Hopkins University Press).

Worthington, L. V., and Volkman, G. H., 1965. The volume transport of the Norwegian Sea overflow water in the North Atlantic. Deep Sea Res., 12:667-676.

Date of Initial Receipt: 16 August 1985

Date of Acceptance: 17 January 1986 